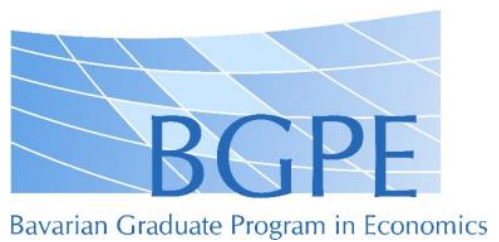

BGPE Discussion Paper

No. 175

\title{
Is there a Glass Ceiling over Germany?
}

\author{
Matthias Collischon
}

November 2017

ISSN 1863-5733

Editor: Prof. Regina T. Riphahn, Ph.D.

Friedrich-Alexander-University Erlangen-Nuremberg

(C) Matthias Collischon 


\title{
Is there a Glass Ceiling over Germany?
}

\author{
Matthias Collischon ${ }^{\mathrm{a}}$ \\ ${ }^{a}$ Friedrich-Alexander University Erlangen-Nürnberg \\ Department of Economics, Lange Gasse 20, 90403 Nürnberg, Germany
}

\begin{abstract}
This paper analyzes the gender wage gap across the wage distribution using 2010 data from the German statistical agency. I investigate East and West Germany and the public sector separately to account for potential heterogeneities in wage gaps. I apply unconditional and conditional quantile regression methods to investigate the differences between highly paid men and women in distributions conditional and unconditional on covariates. The results indicate increasing gender wage gaps in all estimations, suggesting that there is indeed a glass ceiling over Germany even after controlling for a large set of observable characteristics (including occupation and industry). This finding is even more pronounced when also taking bonus payments into account.
\end{abstract}

Keywords: Gender wage gap; gender pay gap; glass ceiling

$J E L: \mathrm{C} 21, \mathrm{~J} 16, \mathrm{~J} 31$

\footnotetext{
This research did not receive any specific grant from funding agencies in the public, commercial, or not-for-profit sectors.

Email address: matthias. collischon@f au.de (Matthias Collischon)
} 


\section{Introduction}

Establishing gender equality in the labor market is a stated goal of policymakers in most states. For example, the G20 established Women20, an initiative to improve women's positions in the labor market (Women20 2017). Closing the gender wage gap to achieve wage equality is important in this respect. However, discussions of wage inequality typically focus on average wage gaps and thus potentially ignore heterogeneities like the glass ceiling effect (an increasing gender wage gap across the wage distribution) that is found in many countries (Albrecht et al. 2003; Felgueroso et al. 2008; Kee 2006; de La Rica et al. 2008). Understanding and acknowledging these heterogeneities is important for policymakers to effectively tackle gender inequalities. For example, raising minimum wages could close gender wage gaps at the bottom of the wage distribution (Dex et al. 2000), while female quotas aim at closing gender gaps for already highly paid employees. Clearly, analyses of mean gaps are insufficient to address the potential effectiveness of such policies. Additionally, gender wage gap investigations in Germany often ignore differences between East and West Germany that could also imply differences in the glass ceiling effect between both regions. To close these blind spots in the literature, I investigate whether there is a glass ceiling over Germany and if it differs between East and West Germany.

The glass ceiling in Germany has been investigated by Antonczyk et al. (2010) and Hübler (2005) with German Data and in cross-national studies (Arulampalam et al. 2007; Christofides et al. 2013). These studies investigate glass ceilings in conditional distributions (an increasing wage differential between men and women who share the same characteristics in the explanatory variables included in the respective models) or decomposition methods based on conditional quantile regressions (CQR). A number of studies investigate gender wage gaps in Germany at the mean (e.g. Finke 2010; Gartner and Hinz 2009; Hinz and Gartner 2005; Hirsch and Schnabel 2013), but only Finke (2010) and Hirsch and Schnabel (2013) investigate wage gaps for East and West Germany separately. Nevertheless, making this distinction is crucial. East Germany still exhibits a higher labor force participation rate of women and women seem to "reject the male breadwinner-model" (Matysiak and Steinmetz 2008, p.331), which may be a consequence of the pre-unification socialist regime. 
These differences could cause the overall smaller raw (without controlling for any covariates) mean wage gap in East Germany, which is only 6\% compared to $24 \%$ in the West (Finke 2010). It is insightful to investigate whether these differences also affect glass ceilings: a higher labor market participation rate of women in East Germany could go along with occupational characteristics and norms that lessen the effect of discrimination compared to West Germany (Goldin 2014).

This paper analyzes the glass ceiling effect for Germany with large-scale survey data from 2010 with nearly 1 million observations, allowing to precisely estimate wage gaps even at the tails of the wage distribution. I investigate gender wage gaps in conditional as well as unconditional wage distributions. Additionally, I decompose gender wage gaps into explained and unexplained components. I also investigate the glass ceiling effect separately for East Germany and for the public sector. Due to strict wage-setting rules as well as the political goal of gender equality, gender wage gaps in the public sector often differ from the private sector (Arulampalam et al. 2007; Barón and Cobb-Clark 2010; Kee 2006).

My contribution to the literature is twofold. First, this is the first study to investigate the glass ceiling effect in wages separately for East Germany and for the German public sector. As described before, there are likely cultural and institutional differences between East and West Germany that previous studies neglected. Second, I compare the glass ceiling effect obtained from three different quantile regression methods, which allows to draw detailed conclusions about the composition of gender wage differentials in Germany. Previous studies mostly investigated glass ceiling with CQR methods or decomposition methods based on these (Arulampalam et al. 2007; Christofides et al. 2013), that compare men and women in conditional wage distributions that depend on covariates included in the estimations and decomposition approaches based on these methods. However, this approach is not suitable to answer questions about whether a connection varies across the unconditional distribution of wages, i.e. comparing overall high-wage women to high-wage men. This aspect of glass ceilings, perhaps even more intuitive than the approach based on conditional distributions, has, to my knowledge, never been investigated for Germany. I investigate glass ceilings with conditional as well as unconditional quantile regression methods and am thus able to draw 
detailed conclusions about glass ceilings in Germany.

My findings indicate significant glass ceilings in West Germany, East Germany and the public sector in conditional as well as unconditional wage distributions. Consistent with previous findings for other countries, observable characteristics cannot explain a large share of gender wage gaps, even when controlling for industry and occupation to rule out sorting mechanisms. Even if these findings do not imply causality, they can be useful information for policymakers. Policies to tackle gender wage gaps need to take these heterogeneities into account and could be tailored to specifically tackle wage gaps for high- or low-wage females. For example, minimum wages or collective agreements could be used to close gender gaps for low-wage employees while more transparent wage-determination structures (as for example required by the "Gesetz zur Förderung der Transparenz von Entgeltstrukturen“which got passed in Germany in 2017) could lead high-wage women to demand closing within-firm gender gaps if they know that they are being disadvantaged.

This paper is composed as follows: section 2 presents several theoretical explanations of pay inequality and derives empirically testable hypotheses. Section 3 section surveys literature on the gender wage gap and glass ceiling in Germany. Section 4 presents the dataset and its potential problems and advantages. Section 5 discusses and compares the econometric methods used in the estimations. Section 6 shows the results of the analyses. Section 7 concludes.

\section{Theoretical Considerations}

\subsection{Discrimination}

Economic theories of discrimination explain mean wage gaps that do not arise through differences in productivity, i.e. wage differentials that are not driven by differences in educational attainment or labor market experience. These theories can be extended to glass ceilings. Taste-based discrimination (Becker 1971) is a reason for wage discrimination of females. Taste-based discrimination argues that employers discriminate against women because their male coworkers could demand a wage premium to work with them or because employers accept costs to discriminate against women. In these cases, wage differentials between men and women are not based on differences in productivity, 
but on a distaste of men against working with females. Considering the glass ceiling, this kind of discrimination could result in a rising wage premium for males across the wage distribution. In practice, male managers could demand a higher wage premium than male office workers, because male office workers are more used to working with women than male managers. Thus, male managers could demand a compensation for working with female colleagues that are rare in their homogeneous group, while office workers are used to gender heterogeneity in their workplace.

The pollution theory of discrimination (Goldin 2014) further expands upon this argument and argues that men could want to prevent women from working in their occupation to maintain their occupational prestige which women could "pollute" by introducing female characteristics that are considered unfit for a certain occupation. This theory could potentially explain glass ceilings, when high-paying jobs like managers are associated with typically male attributes like strength and thus prevent women from entering these positions.

Sociological theories provide explanations for gender wage gaps that are comparable to the theories described before. Ridgeway and Smith-Lovin (1999) argue that gender also incorporates status beliefs which ascribe higher competence to males compared to female and thus justify inequalities, like wage differentials (Ridgeway 2001 provides a comprehensive overview over the sociological theories). Comparable to the pollution theory of discrimination (Goldin 2014), these status beliefs could be more important in highly paid positions, e.g. if women are regarded as incompetent managers.

Monopsonistic discrimination (Hirsch 2009) delivers another explanation for the glass ceiling effect. The basic idea is that men and women differ in the elasticity of their labor supply due to higher mobility. Men's labor supply is elastic, while women's labor supply offerings are restricted due to special conditions like childcare. Firms can use this information to offer equally productive women lower wages than their male counterparts (Barth and Dale-Olsen 2009; Ransom and Oaxaca 2010). One could argue, that highly paid jobs often require higher elasticity of labor supply, e.g. due to working overtime. This would result in a higher wage gap for women at the top end of the wage distribution where high elasticity is needed. 
Lazear and Rosen (1990) and Gobillon et al. (2015) propose theoretical frameworks that explain gender differences along the job ladder which can also explain glass ceilings. There are also sociological theories on occupational segregation through allocative discrimination (for an overview see Reskin 1993) that explain gender differences in the access to certain jobs and positions. However, these theories assume that wage gaps arise through job allocation or self-selection, but can not explain glass ceilings within occupations and industries. In contrast, the other theoretical approaches can also be used to explain wage gaps within industries and occupations. Thus, the frameworks from Lazear and Rosen (1990) and Gobillon et al. (2015) could explain disappearances of gender wage gaps when taking industry and occupation into account.

\subsection{Wage Bargaining}

Gender differences in wage negotiations could be another cause of glass ceilings. Studies (Kaman and Hartel 1994; Stevens et al. 1993; Barron 2003; Babcock and Laschever 2003; Stuhlmacher and Walters 1999) show that women and men have diverging salary expectations and therefore behave differently in pay negotiations. Because the top end of the pay ladder is often very open for variable pay (as for example suggested by the theoretical framework developed in Collischon 2017), these different bargaining styles could produce a glass ceiling effect. The framing of the negotiation situation - or, whether negotiations are taking place at all - is important and, if it is portrayed as a competitive situation (Small et al. 2007), more beneficial for men than women. Female employees tend to prefer non-competitive pay systems, even if competitive pay systems lead to higher wages and non-competitive pay systems can lead to discriminatory wage gaps (Heinz et al. 2016). Men feel entitled to higher wages than women (Heckert et al. 2002; Pelham and Hetts 2001) and both genders perceive lower wages for women as fair (Auspurg et al. 2017). Often, higher-paying jobs are related to a higher share of variable pay. Grund (2015) and Card et al. (2016) show that wage gaps are more pronounced in bonus payments (which I label variable pay) than in fixed wage shares. Thus, gender-specific bargaining styles and related behavior could lead to a glass ceiling effect.

The institutional setting in Germany is important when exploring the relevance of variable pay. While the use of flexible pay schemes and their exact share of overall wages has not yet been 
investigated over the distribution of wages, studies show that the mean share of fixed wages is around 90\% (Bassen et al. 2000) and variable pay is often only used in non-union wages (Kurdelbusch 2002). Nevertheless, wage bargaining seems to gain a more prominent role for new hiring, where individuallevel bargaining happens in one third of all hirings (Brenzel et al. 2014). Because most collective agreements are only applied up to specific wage levels, this absence of regulating institutions could easily produce a glass ceiling.

\subsection{Research Hypotheses}

Discrimination and wage bargaining theories allow to derive testable hypotheses concerning the glass ceiling effect. Even if the connections between variable pay, discrimination, and the gender wage gap are not directly testable at the micro-level, their implications can be tested. As described before, discrimination theories predict glass ceiling either through taste-based discrimination through males, which typically represent a large share of employees in high-paying jobs or through lower levels of labor supply elasticity of females. Likewise, gender differences in wage bargaining could produce glass ceilings. I assume that the share of wages based on individual negotiations is higher for high-wage employees. These pay shares can produce higher gender wage gaps than fixed pay. Either (i) employers use variable pay as a means of discrimination or (ii) women earn less than men because they perform worse in activities relevant for maximizing their variable pay shares, like wage negotiations. Both scenarios would result in an increasing gender wage gap across the wage distribution:

H1: There is a glass ceiling effect for women in wages.

The public sector is heavily affected by laws, collective agreements and strict rules for promotions and wage-setting, and thus should not be subject to individual wage bargaining. In contrast to most private firms, wages are not individually determined but defined in collective agreements that subject all public employees on federal or state level. Additionally, gender discrimination in the public sector is less likely than in the private sector due to strict regulations and the political goal to tackle gender inequality in the workplace. This leads to the following hypothesis: 
$\mathrm{H} 2$ : There is no glass ceiling effect in wages for employees in the public sector.

For the empirical analysis, it is important to define the term glass ceiling to test the hypotheses, because there is no consistent definition of glass ceiling in terms of wages in the literature. In line with Arulampalam et al. (2007), I define the glass ceiling as a widening of the gender wage gap towards the top of the wage distribution, e.g. if the gender wage differential between the 95th percentile and the median is larger than the wage differential between the 90th percentile and the median.

\section{Prior Evidence on Germany}

This section surveys the literature on the gender wage gap and glass ceiling effect in Germany. While there is a vast international literature on glass ceiling effects (e.g. Albrecht et al. 2003; Felgueroso et al. 2008; de La Rica et al. 2008; Kee 2006), previous studies also show that their are large differences between countries (Christofides et al. 2013) due to cultural and institutional aspects. Thus, this section is especially concerned with an overview over previous findings on Germany. The discussion of wage gaps is concerned with unexplained gaps, which means comparing men and women with identical labor market characteristics and human capital endowments (Hirsch and Schnabel 2013; Hinz and Gartner 2005).

Hinz and Gartner (2005), Gartner and Hinz (2009), Hirsch and Schnabel (2013) and Bartolucci (2013) investigate the German gender wage gap with the Linked Employer-Employee (LIAB) dataset. Finke (2010) uses the Verdienststrukturerhebung (VSE) from 2006. These studies account for human capital and occupational variables and find wage gaps between $8 \%$ and $12 \%$ in West Germany, but solely use methods to estimate mean wage gaps. Of these studies, only Finke (2010) and Hirsch and Schnabel (2013) investigate East Germany and find respective unexplained gaps between $7 \%$ and $9 \%$.

Busch and Holst $(2009,2011)$ investigate the gender wage gap in managerial positions in Germany using the German Socio-Economic Panel (SOEP). Their findings indicate a relatively large unexplained wage gap of 12-14\% (Busch and Holst 2009, 2011), even after controlling for 
occupational characteristics in these high-paying positions. The unexplained gap even increases further when accounting for selection into managerial positions. Thus, there findings could be seen as indices for a glass ceiling.

Antonczyk et al. (2010) investigate the connection between collective bargaining, wage inequality and the gender wage gap with data from the Structure of Earnings Surveys 2001 and 2006 using the quantile decomposition method proposed by Melly (2005). Their findings show glass ceilings in both years that are driven by firm-level effects, while the overall increase in women's labor market characteristics leads work towards a reduction of the gender wage gap. This finding is also supported by Kohn and Antonczyk (2013) who find that changes in individual-specific characteristics work towards closing gender wage gaps with data from the Institute of Employment Research (IAB) from 1975 to 2001.

Hübler (2005) investigates the glass ceiling effect with data from the German Socio-Economic Panel from 1984 to 2002 using CQR combined with proensity score matching. His findings indicate that there is a glass ceiling over Germany that disappears over the years investigated when accounting for actual working hours.

Huffman et al. (2017) investigate the effect of organizational policies and practices on the gender wage gap. They use quantile regression methods and describe different impacts of organizational policies across the wage distribution with the LIAB. Their findings indicate that policies that promote diversity and are aimed at disadvantaged groups in the labor market reduce wage gaps at the low-end of the wage distribution, but have hardly any effect on the glass ceiling. The study makes a methodologically as well as theoretically notable contribution to the literature. It uses both the conditional and unconditional or recentered influence function (RIF)-quantile regression and shows that it is important to examine inequality across the full distribution of wages. However, an estimation of the glass ceiling is not the focus of the study, as it deals with the impact of policies on the wage distribution. Estimating the glass ceiling is also hardly possible with the data used because of censoring for high-wage employees, thereby limiting the data at around the 85th percentile of the wage distribution. 
There are also cross-national studies that investigate glass ceilings in Germany (Arulampalam et al. 2007; Christofides et al. 2013) and find respective effects. But these studies yield several problems: since the datasets (EU-SILC and ECHP) have to be harmonized and combined across several countries it leads to a relatively small number of cases when analyzing the tails of the wage distribution. Additionally, the German sample of the EU-SILC under-represents low-educated individuals and over-represents highly-educated ones (Hauser 2008) which could indicate systematic non-responses that could also lead to a bias in variables concerning income and wages. This is especially problematic when investigating low- and high-wage employees. Additionally, Arulampalam et al. (2007) and Christofides et al. (2013) do not account for differences between East and West Germany. This is problematic because there is a significant difference between the wage gaps in East and West Germany (Hirsch and Schnabel 2013) and analyses of the pooled German sample neglect such heterogeneities. Arulampalam et al. (2007) investigate the public sector separately and find a glass ceiling effect, even when controlling for occupation and industry. They argue that the public sector leaves for room for taste-based discrimination because they are typically non-profit and thus could afford inefficient discriminatory behavior. However, their estimations are based on only around 8,500 employees and wide definitions of industry (10 categories) and occupation (3 categories) that potentially do not completely account for sorting.

Thus, the various aspects of gender wage gaps considered in the literature, the previously mentioned issues of the respective studies remain blind spots. I attempt to fill this gap by using large-scale, detailed and recent data on employees in Germany to investigate heterogeneities in gender wage gaps across the wage distribution.

\section{Data}

The analysis uses the scientific use file of the VSE 2010 (also known as the Structure of Earnings Survey) which was collected by the Federal Statistical Agencies in Germany DeStatis (2013b) and samples firms with more than 10 employees. The quality of the data is very high because a substantial share of observations is surveyed directly from the personnel registries of firms (at least in the public 
sector) and participants are required by law to answer correctly. Missing values are imputed. In cases of unclear or implausible information, the statistical agency inquired with respondents. Overall, the VSE contains information on around 1.9 million employees. The participating firms are sampled via quotas on different firms and sectors to prevent random sampling errors (DeStatis 2013b, pp. 5-6). Next, I describe the variables used in the analysis.

The dependent variable is the logarithmic hourly wage. The variable is calculated from regular gross monthly pay and actual working hours. Thus, it does not contain information on e.g. irregular bonus payments. One minor issue is that the values are censored at EUR 750,000 of yearly pay; in these cases ( $\mathrm{n}=81)$, no hourly information is available. However, due to the small number of missing values compared to the large number of valid responses, the missing values should hardly distort results especially because the analysis will investigate specific quantiles. In contrast to Huffman et al. (2017), where the wages are roughly censored at the 85 th percentile of the distribution, the censoring in my case does not lead to the loss of a substantial share of the information on wages (81 censored of 941,168 total observations are less than $0.01 \%$ of the sample). Table 1 presents an overview of the wages of men and women and wage gaps for different subsamples. This table shows descriptive evidence that all subsamples experience a drastic rise in the wage differential between men and women over the respective wage distribution, rising from around EUR $0.60(7.85 \%)$ at the 5th percentile to above EUR $12(29.83 \%)$ at the 95th percentile in the full sample. This is an indicator for the glass ceiling effect. Figure 1 displays the raw gender wage gaps at the mean and across the respective wage distributions. This descriptive analysis shows that there are indeed heterogeneities in the raw gender wage gap across the wage distribution.

The data include a large number of control variables. Tenure is directly reported in the data. Tenure may not directly be affected by gaps or events in the labor market career such as parental leave that is even supported by some firms if the respondent did not quit during childcare. Tenure is calculated as the survey year minus the year the respondent started working at his or her employer. Therefore, mothers who return from parental leave experience no gap in tenure. Labor market 
experience is not directly reported in the data but is computed as potential experience ${ }^{1}$ and is included in the wage regression with squared, cubic and quartic polynomials (which provides a better fitting than a quadratic specification; Murphy and Welch 1990). ${ }^{2}$ The data also contain information on education ${ }^{3}$, the region the firm is located (East and West), shift work, temporary employment, working hours, and full-time employment (dummy).

I control for the institutional setting as well to estimate the direct wage effect of gender discrimination and rule out sorting mechanisms. Institutional information in the data consist of occupation and the industrial sector, reported as the International Standard Classification of Occupations (ISCO) 08 classification (2-digits) and the Classification of Industry branches 2008 (WZ-2008; 2-digits) from DeStatis (2007). Additionally, the data provide information on the performance group of employees (e.g. indicating if employees have managerial responsibilities, carry out complex tasks or have no decision-making responsibilities) and if the employee is a craftsman. Public sector employment is reported in the data. However, in this context, public sector employment indicates that $50 \%$ or more of the firm shares belong to public institutions. Other institutional control variables are collective bargaining regimes and firm size.

The analysis excludes apprentices, employees in partial retirement and the marginally employed. ${ }^{4}$ With missing values due to data anonymization (DeStatis 2013a), this results in 941,087 cases in the analysis. Table 2 shows descriptive statistics of the variables included in the final dataset.

\footnotetext{
${ }^{1}$ Potential experience is calculated as age - years of education - 6. Six is the typical school-entry age in Germany.

${ }^{2}$ One might argue that potential experience and tenure in my case do not account for gaps due to e.g. childbearing leads to a bias in the estimations. However, Gartner and Hinz (2009) report that using observed rather than potential experience in gender wage gap estimations with data from the IAB hardly changes the results.

${ }^{3}$ I recalculate education to years of education in my analysis. However, using indicator variables for the different educational degrees does not significantly change the results.

${ }^{4}$ Marginal employment in this case is the German "Minijob", a subsidized form of employment with maximum wages of 450 Euro per month.
} 


\section{Econometric Methods}

\subsection{Conditional Quantile Regression $(C Q R)$}

In contrast to standard OLS-regression, the CQR allows for the estimation of effects at various points of the conditional distribution of the dependent variable (Koenker and Bassett 1978). CQR produces within-group comparisons of a variable of interest where the other covariates are used to determine the specific group. In the case of the gender wage gap, conditional quantile regressions show the wage differential between men and women who are otherwise identical in their covariates. For example, in a simple regression model on wages with education and gender as independent variables, conditional quantile regression compares the wages of women with the wages of men who share the same education at different quantiles of the conditional wage distribution (Killewald and Bearak 2014). Standard errors are obtained by bootstrapping.

\subsection{Unconditional Quantile Regression $(U Q R)$}

Investigating the glass ceiling with the unconditional quantile regression (UQR) highlights another aspect of the glass ceiling effect. This estimation method focuses on the unconditional quantiles of the wage distribution. Firpo et al. (2009) proposed to estimate the UQR via the RIFapproach. The basic idea is to replace the dependent variable in a standard linear regression with the outcome for a statistic of interest, like a specific quantile ${ }^{5}$. This is achieved by computing the influence function for this specific quantile. The influence function (Hampel 1974, 1986) can be written as:

$$
I F\left(Y, Q_{\tau}\right)=\frac{\tau-\nVdash\left\{Y<Q_{\tau}\right\}}{f_{y}\left(Q_{\tau}\right)}
$$

Where $\tau$ is the percentile of interest, $\nVdash\left\{Y<Q_{\tau}\right\}$ is an indicator function that can take the values 0 or 1 given the condition in parentheses and $f_{y}$ is the density function of the marginal distribution at $Q_{\tau}$,

\footnotetext{
${ }^{5}$ Firpo et al. (2009) also propose a logit and non-parametric approach using RIFs. However, to ensure comparability with previous findings (Huffman et al. 2017) and because the results often hardly differ (Firpo et al. 2009), I will use the OLS approach.
} 
which is obtained using a kernel density estimation (Epanechnikov 1969). The RIF-concept simply extends this approach by adding the population quantile of choice $Q_{\tau}$ to the influence function.

$$
R I F\left(Y, Q_{\tau}\right)=Q_{\tau}+\frac{\tau-\nVdash\left\{Y<Q_{\tau}\right\}}{f_{y}\left(Q_{\tau}\right)}
$$

This model is usually computed as a linear regression model at different points of the distribution (Fortin et al. 2011, pp. 76-82). While CQR estimations use the set of covariates to construct conditional distributions, the UQR estimates impacts of regressors on the unconditional distribution, controlling for covariates.

\subsection{Decomposition Approach}

In contrast to standard regression models that only show mean differences between men and women, decomposition analyses allow for a different approach: what if men (or women) had the same coefficients in the covariates as women (or men)? While CQR, UQR and OLS assume identical returns to characteristics for men and women, decomposition methods decompose wage gaps in explained parts (due to different characteristics, e.g. differences in human capital) and unexplained parts (due to different returns to these characteristics).

One widely used method in economics to investigate discrimination is the Oaxaca-Blinder (OB, Oaxaca 1973; Blinder 1973) decomposition, which is often used to investigate gender wage gaps (Arulampalam et al. 2007; Christofides et al. 2013; Finke 2010). However, the OB approach does not allow for a decomposition at different quantiles. A similar decomposition method based on quantile regression was proposed by Machado and Mata (2005) and further advanced by Melly (2005) and Chernozhukov et al. (2013). Like the OB decomposition, this method simulates counterfactual distributions that would prevail if women had the same wage structure as men or vice versa.

This paper uses the decomposition method by Chernozhukov et al. (2013) to estimate the gender wage gap. This procedure will be referred to as the "CFM"(Chernozhukov-Fernandez-Val-Melly) method hereafter. The basic idea is to estimate conditional quantile regressions for each group (men and women) and extracting counterfactual distributions, similar to the idea of the OB approach. This 
method estimates wage differences within groups in conditional distributions, but estimates between group differences by comparing conditional and counterfactual distribution. Therefore, it is likely that the decomposition results are closer to the UQR than the CQR. While the CQR as well as the UQR show wage differences at certain points of wage distributions, this approach estimates wage gaps for men if they had women's returns to their human capital characteristics and vice versa. It explores a different aspect of wage discrimination that can also be interpreted as a glass ceiling effect.

Because the CFM decomposition method shares the same attributes as the original OaxacaBlinder (OB) decomposition when it comes to the reference group, it also shares the "index number problem“. This problem refers to varying results in the decompositions based on the reference wage structure. For example, Ferber and Green (1982) find an unexplained yearly gender wage gap of USD 98 using the female wage structure and a gap of USD 3,236 using the male wage structure. Thus, I estimate models with male and female wage structures as reference points and compare the results. This point is neglected by Arulampalam et al. (2007) and Christofides et al. (2013) who only use the female wage structure as the reference point in their estimations.

To summarize, all estimation approaches make different, but nevertheless valuable contributions to test the research hypotheses. While the conditional quantile regression answers the question "How large is the wage differential between men and women who share the same characteristics at a conditional quantile of interest?", the UQR answers the question "How large is the wage differential for low-wage employees? And how large is it for high-wage employees?“. While the CQR provides a within-group comparison of employees that share the same characteristics, e.g. education, occupation, etc., the UQR simply compares high- to low-wage employees which is perhaps a more intuitive definition of glass ceilings. The decomposition analyzes the question "How large are the differences that arise through different returns to covariates for men and women across the wage distribution?". Additionally, using multiple methods also ensures comparability of the results to the previous findings that just used CQR and the CFM decomposition. All three methods 
are useful to investigate glass ceilings and cover different aspects of these. ${ }^{6}$

\section{Results}

\subsection{Conditional Quantile Regression (CQR)}

This section presents the results of the CQR-estimations. Because estimating the standard errors via bootstrapping is computationally intensive, these results are estimated with a randomly drawn $30 \%$-subsample of 282,326 observations and 50 bootstrap repetitions.

Table 3 shows the gender wage gap across the conditional distribution with a step wise introduction of the covariates. ${ }^{7}$ The first model in panel A only shows the gender coefficient, without any control variables except for region. The negative wage correlation for women rises across the distribution of wages, from a significant gender wage gap of $7 \%$ at the 5 th percentile to $28.7 \%$ at the 95th percentile ${ }^{8}$. This first analysis indicates a glass ceiling effect, because the gender wage gaps increase across the wage distribution. Table 3, panel B adds human capital variables. The gender wage gap at the lower deciles rises, while the gaps in the middle and upper part of the distribution decline. This could be the effect of a selection of women with relatively high human capital into lower wage jobs, for example through the choice of occupation. Finally, Table 3, panel C shows the full model. The results are additionally plotted in Figure 2. In addition to human capital variables, it includes indicators for occupation and job characteristics. This decreases the wage gap at all points of the conditional distribution. The wage gap at the 95 th percentile equals $12.3 \%$ in contrast to $7.9 \%$ at the median and around $9.4 \%$ at the mean. The results indicate a glass ceiling effect, thus supporting hypothesis H1. Compared to prior findings using CQR, the patterns of the estimations are comparable to Albrecht et al. (2003) for Sweden and the US and Kee (2006) for Australia who

\footnotetext{
${ }^{6}$ Killewald and Bearak (2014) provide a comprehensive comparison of conditional and unconditional quantile regression while Fortin et al. (2011) provide a comprehensive overview over decomposition techniques. Additionally, a comparison of the methods and further explanations are presented in the appendix.

${ }^{7}$ This approach should nevertheless be interpreted with caution, because the changes in the gender wage gap through introducing covariates could depend on the order the covariates are introduced (Gelbach 2016). However, to my knowledge, this problem cannot easily be fixed in a CQR-framework.

${ }^{8}$ The wage difference in percent can be obtained by calculating $\exp (\beta)-1$.
} 
report increasing wage gaps across the conditional wage distributions, even when controlling for occupation and industries.

The gender wage gap in Germany differs between West and East Germany (Hirsch and Schnabel 2013). The separate estimations for East and West Germany in panels B and C of Table 4 show some remarkable differences: the gender wage gap is much smaller for East Germany, but there is still evidence for a glass ceiling. Nevertheless, the wage gap of $10.1 \%$ at the 95 th percentile of the conditional distribution for East Germany is hardly wider than gap of $9.5 \%$ at the the mean in West Germany (see OLS column). However, the rise in the wage gap across the conditional distribution is nearly identical for both regions of Germany. Again, the findings support hypothesis H1.

Considering the wage gap in the public sector, the CQR-estimation shows mostly smaller wage differentials than in the other cases (Table 4, panel D). Despite the generally smaller gaps, the wage gaps still increase significantly across the wage distribution. Therefore, hypothesis $\mathrm{H} 2$ has to be rejected; there is a glass ceiling in the public sector as well. However, it should be noted that even the wage gap at the 95th percentile in the public sector is still smaller than the median wage gap in the estimation for the pooled sample. These findings are comparable to results for Australia (Kee 2006) in which the gender wage gap also increases across the conditional wage distribution in the public sector, but remains smaller than the private sector wage gap. Interestingly, the mean wage gap in the public sector is as large as the wage gap at the 95th conditional quantile. This indicates that the wage gap over the unconditional wage distribution (discussed in the next subsection on the UQR results) might be larger than in the CQR-case.

Overall, the results indicate glass ceilings in all samples investigated. Thus, there is an increasing gender wage gap across the wage distribution, even within groups of employees that share the same characteristics, e.g. men and women within the same occupation. This suggests that sorting mechanisms cannot fully explain gender wage differentials.

\subsection{Unconditional Quantile Regression (UQR)}

This section discusses the results of the UQR estimations. The results are displayed in Table 5 and Figure 3. Table 5, panel A shows the results for the full sample. The results largely support 
the results of the conditional quantile regression, but show even larger differentials at the tails of the distribution: in contrast to a gap of around $6.2 \%$ at the 5 th percentile and $12.5 \%$ at the 95 th percentile in the conditional quantile regression, the UQR-estimation leads to gaps of $3.1 \%$ at the 5th percentile and a large gap of $18.4 \%$ at the 95th percentile with significant increases across the quantiles investigated. This strongly suggests the existence of a glass ceiling. The findings are in line with the only other study that uses UQR with German data (Huffman et al. 2017) and shows that the largest gender wage gaps are found among high-wage employees.

Table 5, panels B and C show the results for the separate regressions for East and West Germany. The UQR results follow the same pattern displayed in the CQR results: the regressions for East as well as West Germany indicate glass ceilings, thus supporting hypothesis H1.

The second hypothesis concerning the public sector is also tested with the UQR, the results are reported in Table 5, panel D. There is even a small advantage of $1.4 \%$ for women at the 5 th percentile. The gender wage gap up to the median increases to a relatively small $3 \%$. However, this first impression does not hold in the upper wage categories, with a highly significant wage gap of $10.7 \%$ at the 90 th percentile. The wage gap keeps rising up to the 95th percentile. These results strongly suggest the existence of a glass ceiling in the public sector and further support the results of the CQR. Therefore, hypothesis $\mathrm{H} 2$ has to be rejected. Interestingly, there is a large difference between the estimated wage differentials in the CQR and UQR case. The conditional estimation, which compares employees with the same characteristics, leads to much smaller wage gaps in the higher percentiles than the method which is based on the unconditional distribution; the wage gap at the 95th percentile is more than twice as large in the UQR estimations compared to CQR. This indicates that the conditional and unconditional distribution of wages for the public sector differ largely.

This correlation pattern is not, at least to this extent, present in the other estimations. There might be a selection of males into high-paying positions in the public sector that does not occur in the private sector because the private sector generally pays higher wages. Additionally, selection effects could also lead to different results when women do systematically take relatively low-paid positions 
within an occupation in the public sector because they accept wage penalties to have access to higher job security or maternal leave policies. Both effects together could lead to these significantly different estimations and are perhaps not accounted for with the set of control variables if there is still room for hierarchical differences within the definition of occupation, which, even in case of the 2-digit ISCO, is still possible, perhaps even when accounting for performance groups, which should nevertheless capture a large part of this variation. This could also lead to the, in general, larger wage gaps obtained through UQR in the other samples.

Overall, while the $\mathrm{CQR}$ shows that there are within-group glass ceilings (in wage distributions conditional on covariates), the UQR shows that these differentials also translate into glass ceilings in unconditional wage distribution, comparing high-wage men to high-wage women.

\subsection{Decomposition}

This section presents the results of the CFM decomposition. Because the decomposition is computationally intensive, the same $30 \%$-subsample as in the conditional quantile regression case is used. Additionally, no standard errors were computed due to the high number of quantile regressions estimated (100 per sample and reference wage structure) and because the large sample size should generally lead to small standard errors comparable to the other estimations.

The results for the sample with no additional exclusions as well as the different subsamples are shown in Table 6 and Figure 4. The results of the decompositions largely confirm the estimates obtained by quantile regression: the rise of the gender wage gap is mostly linear over the distribution of wages. While the decomposition methods present smaller wages at the lower end of the distribution, there is still solid evidence for the existence of glass ceilings, in line with previous findings for Germany using quantile decomposition methods. Arulampalam et al. (2007) find an unexplained gender wage gap from 6\% (10th percentile) to $15.7 \%$ (90th percentile) for the German private sector using the Machado-Mata decomposition that is very similar to my results which show a wage gap of $5 \%$ (10th percentile) to $11.9 \%$ (90th percentile) with the same reference wage structure, but with a more sophisticated set of controls. Similarly, Antonczyk et al. (2010) and Christofides et al. (2013) find glass ceilings in Germany using Machado-Mata decompositions. Compared to international 
literature using decomposition methods, the unexplained wage gap in Germany is smaller than in Australia (Kee 2006) and comparable to Sweden (Albrecht et al. 2003).

The findings also indicate a glass ceiling in the public sector, which is consistent with findings for Australia (Kee 2006) and European countries (Arulampalam et al. 2007). Due to the decomposition into explained and unexplained parts of the gender wage gap, this analysis reveals some important details. While all estimations yield a rise of the unexplained gap across the distribution of wages, the explained part even declines in the public sector at the 95 percentile compared to the 90th and 75th percentile (see Table 6, panel $\mathrm{H}$ ). In the estimation for the public sector with the female wage structure as the reference point (Table 6, panel H), the explained part even works in favor of women at the 5th percentile. This finding is particularly interesting compared to the literature. Kee (2006) finds a similar phenomenon for the Australian public sector at the 75th and 90th percentile of the wage distribution which suggests that in the Australian public sector, high-paid women exhibit more favorable labor market characteristics than men. Arulampalam et al. (2007) support the findings for Germany and report similar results for Austria, Ireland, Italy and Spain. This suggest that women in the public sector overall are positively selected. Potentially, this is driven by benefits such as better childcare opportunities and less overtime work compared to the private sector which might be more important for women compared to men. While the CFM method is based on the conditional quantile regression and therefore not directly comparable to the UQR-results, it still indicates a selection of comparably well-endowed women into relatively low positions in the public sector.

The estimations for East Germany (see Table 6, panels E and F) also report a positive selection of women into the labor market up to the median (with the female wage structure as the reference point), in contrast to West Germany. However, all estimations nevertheless indicate glass ceilings.

The decomposition results show that the choice of the reference wage structure does indeed affect the results in economically important ways. Even though all estimations show glass ceilings, the unexplained gaps often differ largely between the male and female reference wage structure. For example, the unexplained wage gap at the median in the public sector using the female wage structure as the reference point (Table 6, panel $\mathrm{H}$ ) is twice as large as the same estimation with the 
male wage structure (Table 6, panel G). Thus, it is important to consider both wage structures as reference points.

Overall, my results show glass ceilings for women regardless of the econometric approach used in West Germany, East Germany and the public sector. Thus, there are glass ceiling within groups conditional on covariates, i.e. men and women within the same occupation, industry with equal endowments in human capital variables etc., as well as in the unconditional wage distribution.

\subsection{Sensitivity Analysis: Including bonus payments}

The hourly wages used in the main analysis are solely based on contractual monthly pay, but do not include irregular bonus payments like performance premia or paid overtime work. However, Card et al. (2016) and Grund (2015) show that there is a wage gap in bonus payments and that women are less likely to work in firms paying such premia. Thus, it can be insightful to investigate wage gaps including bonus payments.

The VSE includes information on yearly pay including bonus payments as well yearly working weeks and information on contractual working hours and paid overtime work. Based on this information, I calculate hourly wages including bonus payments. Due to missing values in some variables, the number of cases drops to 938,252 . In line with the main analysis, I investigate wage gaps with $\mathrm{CQR}, \mathrm{UQR}$ and the CFM decomposition.

Table 7 and Figure 5 show the results for the full sample. As expected and in line with the literature, including bonus payments does lead to a modest increase in gender wage gaps across the wage distribution in all estimations. Again, the results show that reference wage structure in the decomposition analysis significantly alters the results, as shown in the larger wage gaps with the female wage structure as the reference point. However, this does not change the results concerning the hypotheses.

\section{Conclusion}

This paper investigates the glass ceiling effect in Germany with conditional and unconditional quantile regression methods and the CFM decomposition. I investigate three different aspects of the 
glass ceiling: (i) glass ceilings in conditional wage distributions, which compare men and women in conditional distributions who share the same characteristics in covariates, (ii) glass ceilings in unconditional wage distributions, thus comparing high-wage men to high-wage women, and (iii) glass ceilings if men had women's returns to their characteristics and vice versa. The results show a robust glass ceiling effect in all estimations that remains when controlling for human capital and job characteristics and becomes even more pronounced when including bonus payments. Even if the effect is smaller in East Germany, it is as well present in this region. The findings hold for high-wage women in wage distributions conditional and unconditional on covariates. The rise in the gender wage gap across the distribution of wages can only partly be explained by different characteristics, as the decompositions show. The results are robust to changing the reference wage structure. Thus, regardless of the method used, different human capital endowments, allocative discrimination or self-selection into specific occupations, industries or performance groups cannot explain the increase in the gender wage gap across the wage distribution in Germany.

There is a glass ceiling for employees of the public sector, which is the most strictly regulated by collective agreements and laws, even when controlling for detailed indicators for industry and occupation. This finding is somewhat surprising, but could potentially be explained by the larger independence of public employers from market-mechanisms compared to the private sector, which could give employers room to discriminate without having to fear competitive disadvantages when discrimination is not efficient, as suggested by Kee (2006) who also finds a glass ceiling in the Australian public sector. Additionally, pay increases in the public sector are often automatically linked to tenure. Thus, if the variable that measures tenure in my data does not account for career interruptions, e.g. due to parental leave, this could lead to a bias in the estimations of the gender gaps if females experience more interruptions compared to men. Nevertheless, one should keep in mind that the public sector - in all estimations - produces smaller wage gaps than all other samples investigated.

However, this study also has important limitations that could stimulate further research. First, the data used in the analyses only covers firm with 10 or more employees. It would be interesting 
to investigate gender wage gaps in small firms who face somewhat different regulatory institutions compared to their large counterparts, for example in the protection against dismissals. Second, as mentioned before, the measures for potential experience and tenure used in the analysis do not necessarily capture career interruptions due to e.g. childbearing. Thus, I potentially overestimate tenure and experience especially for females. Third, even if the data contain a large set of controls, there might still be biases due to unobserved heterogeneity. For example, gender wage differentials could be driven by systematic differences in non-cognitive skills between men and women.

The large gender wage gap that remains even after controlling for observable characteristics in all estimations raises the question which policies could be used to reach the political goal of gender equality in pay. It remains to be seen if laws like the "Gesetz zur Förderung der Transparenz von Entgeltstrukturen“ in Germany lead to an increase in the demand for equal wages by women. The availability of information on the mean pay could also be seen as information on how wide their personal wage gap is within the firm. Female employees could thus adjust their wage expectations and are probably more likely to demand higher wages if they know what their male colleagues earn. The bill could also lead to a self-imposed adjustment of male and female wages by the employer. Because the gender differences in earnings are especially pronounced for high-wage employees, it will be interesting to see if and how this and comparable laws affect gender wage differentials.

\section{Acknowledgments}

The author would like to thank Sabine Ebensperger, Andreas Eberl, Albrecht Glitz, Daniel Kühnle, Dominique Lemmermann, Malte Reichelt, Regina T. Riphahn, Salwan Saif, three anonymous referees and the participants of the seminar "Rational Choice Sociology: Theory and Empirical Applications“" in Venice 2016 for their helpful comments. 


\section{References}

Albrecht, J., A. Björklund, and S. Vroman (2003). Is There a Glass Ceiling in Sweden? Journal of Labor Economics 21(1), 145-177.

Antonczyk, D., B. Fitzenberger, and K. Sommerfeld (2010). Rising wage inequality, the decline of collective bargaining, and the gender wage gap. Labour Economics 17(5), 835-847.

Arulampalam, W., A. L. Booth, and M. L. Bryan (2007). Is there a glass ceiling over Europe? Exploring the gender pay gap across the wage distribution. Industrial and Labor Relations Review 60(2), 163-186.

Auspurg, K., T. Hinz, and C. Sauer (2017). Why should women get less? evidence on the gender pay gap from multifactorial survey experiments. American Sociological Review 82(1), 179-210.

Babcock, L. and S. Laschever (2003). Women don't ask: Negotiation and the gender divide. Princeton, New Jersey: Princeton University Press.

Barón, J. D. and D. A. Cobb-Clark (2010). Occupational Segregation and the Gender Wage Gap in Private- and Public-Sector Employment: A Distributional Analysis. Economic Record 86(273), $227-246$.

Barron, L. A. (2003). Ask and you shall receive? Gender differences in negotiators' beliefs about requests for a higher salary. Human Relations 56(6), 635-662.

Barth, E. and H. Dale-Olsen (2009). Monopsonistic discrimination, worker turnover, and the gender wage gap. Labour Economics 16(5), 589 - 597.

Bartolucci, C. (2013). Gender Wage Gaps Reconsidered: A Structural Approach Using Matched Employer-Employee Data. Journal of Human Resources 48(4), 998-1034.

Bassen, A., M. Koch, M. Pertl, and D. Wichels (2000). Variable Entlohungssysteme in Deutschland. Eine empirische und fallstudienbasierte Studie. Finanz-Betrieb 2(1), 9-17. 
Becker, G. S. (1971). The Economics of Discrimination (2nd ed ed.). Chicago: University of Chicago Press.

Blinder, A. S. (1973). Wage discrimination: reduced form and structural estimates. Journal of Human Resources 8(4), 436-455.

Brenzel, H., H. Gartner, and C. Schnabel (2014). Wage bargaining or wage posting? Evidence from the employers' side. Labour Economics 29, 41-48.

Busch, A. and E. Holst (2009). Glass Ceiling Effect and Earnings - The Gender Pay Gap in Managerial Positions in Germany. DIW Discussion Paper 905.

Busch, A. and E. Holst (2011). Gender-Specific Occupational Segregation, Glass Ceiling Effects, and Earnings in Managerial Positions: Results of a Fixed Effects Model. SOEP Discussion Paper 357.

Card, D., A. R. Cardoso, and P. Kline (2016). Bargaining, Sorting, and the Gender Wage Gap: Quantifying the Impact of Firms on the Relative Pay of Women. The Quarterly Journal of Economics 131(2), 633-686.

Chernozhukov, V., I. Fernandez-Val, and B. Melly (2013). Inference on Counterfactual Distributions. Econometrica 81(6), 2205-2268.

Christofides, L. N., A. Polycarpou, and K. Vrachimis (2013). Gender wage gaps, 'sticky floors' and 'glass ceilings' in Europe. Labour Economics 21, 86-102.

Collischon, M. (2017). The Returns to Personality Traits across the Wage Distribution. SOEP Discussion Paper 921.

de La Rica, S., J. J. Dolado, and V. Llorens (2008). Ceilings or floors? gender wage gaps by education in spain. Journal of Population Economics 21(3), 751-776.

DeStatis (2007). Klassifikation der Wirtschaftszweige, Ausgabe 2008 (WZ 2008). Wiesbaden: Statistisches Bundesamt. 
DeStatis (2013a). Scientific-Use-File zu Verdienststrukturerhebung 2010 - Anonymisierungskonzept und Metadaten. Wiesbaden: Statistisches Bundesamt.

DeStatis (2013b). Verdienststrukturerhebung - Qualitätsbericht: Erhebung der Struktur der Arbeitsverdienste nach $\$ 4$ Verdienststatistikgesetz. Wiesbaden: Statistisches Bundesamt.

Dex, S., H. Sutherland, and H. Joshi (2000). Effects of minimum wages on the gender pay gap. National Institute Economic Review 173(1), 80-88.

Epanechnikov, V. A. (1969). Non-parametric estimation of a multivariate probability density. Theory of Probability and Its Applications 14(1), 153-158.

Felgueroso, F., M. J. Pérez Villadóniga, and J. Prieto-Rodriguez (2008). The effect of the collective bargaining level on the gender wage gap: Evidence from spain. The Manchester School 76(3), $301-319$.

Ferber, M. A. and C. A. Green (1982). Traditional or Reverse Sex Discrimination? A Case Study of a Large Public University. Industrial and Labor Relations Review 35(4), 550.

Finke, C. (2010). Verdienstunterschiede zwischen Männern und Frauen. Wiesbaden: Statistisches Bundesamt.

Firpo, S., N. M. Fortin, and T. Lemieux (2009). Unconditional Quantile Regressions. Econometrica $77(3), 953-973$.

Fortin, N., T. Lemieux, and S. Firpo (2011). Decomposition Methods in Economics. In O. Ashenfelter and D. Card (Eds.), Handbook of Labor Economics, Volume 4, pp. 1-102. Amsterdam: North Holland.

Gartner, H. and T. Hinz (2009). Geschlechtsspezifische Lohnungleichheit in Betrieben, Berufen und Jobzellen (1993-2006). Berliner Journal für Soziologie 19(4), 557-575.

Gelbach, J. B. (2016). When do covariates matter? and which ones, and how much? Journal of Labor Economics 34(2), 509-543. 
Gobillon, L., D. Meurs, and S. Roux (2015). Estimating Gender Differences in Access to Jobs. Journal of Labor Economics 33(2), 317-363.

Goldin, C. (2014). A Pollution Theory of Discrimination: Male and Female Differences in Occupations and Earnings. In Leah Platt Boustan, Carola Frydman, and Robert A. Margo (Eds.), Human Capital in History: The American Record, pp. 313-348. University of Chicago Press.

Grund, C. (2015). Gender pay gaps among highly educated professionals - Compensation components do matter. Labour Economics 34, 118-126.

Hampel, F. R. (1974). The influence curve and its role in robust estimation. Journal of the American Statistical Association 69(346), 383-393.

Hampel, F. R. (1986). Robust statistics: The approach based on influence functions. New York: Wiley.

Hauser, R. (2008). Problems of the German Contribution to EU-SILC-A Research Perspective, Comparing EU-SILC, Microcensus and SOEP. RatSWD Working Paper No. 20.

Heckert, T. M., H. E. Droste, P. J. Adams, C. M. Griffin, L. L. Roberts, M. A. Mueller, and H. A. Wallis (2002). Gender differences in anticipated salary: Role of salary estimates for others, job characteristics, career paths, and job inputs. Sex Roles 47(3), 139-151.

Heinz, M., H.-T. Normann, and H. A. Rau (2016). How competitiveness may cause a gender wage gap: Experimental evidence. European Economic Review 90, 336-349.

Hinz, T. and H. Gartner (2005). Geschlechtsspezifische Lohnunterschiede in Branchen, Berufen und Betrieben/The Gender Wage Gap within Economic Sectors, Occupations, and Firms. Zeitschrift für Soziologie 34(1), 22-39.

Hirsch, B. (2009). The Gender Pay Gap under Duopsony: Joan Robinson meets Harold Hotelling. Scottish Journal of Political Economy 56(5), 543-558. 
Hirsch, B. and C. Schnabel (2013). Geschlechterlohnlücke: gerechtfertigt oder diskriminierend? PERSONALquaterly 65(3), 9-14.

Hübler, O. (2005). Is there a varying unexplained gender wage gap in germany? Applied Economics Quarterly 51(1), 29-48.

Huffman, M. L., J. King, and M. Reichelt (2017). Equality for Whom? Organizational Policies and the Gender Gap across the German Earnings Distribution. ILR Review 70(1), 16-41.

Kaman, V. S. and C. E. J. Hartel (1994). Gender differences in anticipated pay negotiation strategies and outcomes. Journal of Business and Psychology 9(2), 183-197.

Kee, H. J. (2006). Glass ceiling or sticky floor? Exploring the Australian gender pay gap. Economic Record 82(259), 408-427.

Killewald, A. and J. Bearak (2014). Is the Motherhood Penalty Larger for Low-Wage Women? A Comment on Quantile Regression. American Sociological Review 79(2), 350-357.

Koenker, R. and G. Bassett (1978). Regression quantiles. Econometrica 46(1), 33-50.

Kohn, K. and D. Antonczyk (2013). The aftermath of reunification. Economics of Transition 21(1), $73-110$.

Kurdelbusch, A. (2002). Multinationals and the Rise of Variable Pay in Germany. European Journal of Industrial Relations 8(3), 325-349.

Lazear, E. P. and S. Rosen (1990). Male-Female Wage Differentials in Job Ladders. Journal of Labor Economics 8(1), S106-S123.

Machado, J. A. F. and J. Mata (2005). Counterfactual decomposition of changes in wage distributions using quantile regression. Journal of applied Econometrics 20(4), 445-465.

Matysiak, A. and S. Steinmetz (2008). Finding Their Way? Female Employment Patterns in West Germany, East Germany, and Poland. European Sociological Review 24(3), 331-345. 
Melly, B. (2005). Decomposition of differences in distribution using quantile regression. Labour Economics 12(4), 577-590.

Murphy, K. M. and F. Welch (1990). Empirical age-earnings profiles. Journal of Labor Economics 8(2), 202-229.

Oaxaca, R. (1973). Male-female wage differentials in urban labor markets. International Economic Review 14(3), 693-709.

Pelham, B. W. and J. J. Hetts (2001). Underworked and Overpaid: Elevated Entitlement in Men's Self-Pay. Journal of Experimental Social Psychology 37(2), 93-103.

Ransom, M. R. and R. L. Oaxaca (2010). New Market Power Models and Sex Differences in Pay. Journal of Labor Economics 28(2), 267-289.

Reskin, B. (1993). Sex segregation in the workplace. Annual Review of Sociology 19, 241-270.

Ridgeway, C. L. (2001). Gender, status, and leadership. Journal of Social Issues 57(4), 637-655.

Ridgeway, C. L. and L. Smith-Lovin (1999). The gender system and interaction. Annual Review of Sociology 25(1), 191-216.

Small, D. A., M. Gelfand, L. Babcock, and H. Gettman (2007). Who Goes to the Bargaining Table? The Influence of Gender and Framing on the Initiation of Negotiation. Journal of Personality and Social Psychology 93(4), 600-613.

Stevens, C. K., A. G. Bavetta, and M. E. Gist (1993). Gender differences in the acquisition of salary negotiation skills: The role of goals, self-efficacy, and perceived control. Journal of Applied Psychology 78(5), 723-735.

Stuhlmacher, A. F. and A. E. Walters (1999). Gender differences in negotiation outcome: a metaanalysis. Personnel Psychology 52(3), 653-677.

Women20 (2017). Communiqué Women20 Germany. Berlin: W20. 
Tables

Table 1: Distribution of the hourly wages

\begin{tabular}{|c|c|c|c|c|c|c|c|c|}
\hline & $\begin{array}{c}5^{t h} \\
\text { Percentile }\end{array}$ & $\begin{array}{c}10^{t h} \\
\text { Percentile }\end{array}$ & $\begin{array}{c}25^{t h} \\
\text { Percentile }\end{array}$ & $\begin{array}{c}50^{t h} \\
\text { Percentile }\end{array}$ & $\begin{array}{c}75^{\text {th }} \\
\text { Percentile }\end{array}$ & $\begin{array}{c}90^{t h} \\
\text { Percentile }\end{array}$ & $\begin{array}{c}95^{t h} \\
\text { Percentile }\end{array}$ & Mean \\
\hline \multicolumn{9}{|c|}{ Overall } \\
\hline Male & 7.77 & 9.21 & 12.64 & 17.58 & 24.77 & 33.99 & 41.17 & 20.42 \\
\hline Female & 7.16 & 8.27 & 10.83 & 14.44 & 19.02 & 24.34 & 28.89 & 15.76 \\
\hline Wage gap & $7.85 \%$ & $10.21 \%$ & $14.32 \%$ & $17.86 \%$ & $23.21 \%$ & $28.39 \%$ & $29.83 \%$ & $22.82 \%$ \\
\hline \multicolumn{9}{|c|}{ West Germany } \\
\hline Male & 8.63 & 10.29 & 13.64 & 18.55 & 25.89 & 35.26 & 42.86 & 21.56 \\
\hline Female & 7.92 & 8.75 & 11.50 & 15.05 & 19.69 & 25.04 & 29.68 & 16.43 \\
\hline Wage gap & $8.23 \%$ & $14.97 \%$ & $15.69 \%$ & $18.87 \%$ & $23.95 \%$ & $28.89 \%$ & $30.75 \%$ & $23.79 \%$ \\
\hline \multicolumn{9}{|c|}{ East Germany } \\
\hline Male & 6.45 & 7.25 & 9.14 & 13.05 & 18.87 & 26.42 & 31.91 & 15.38 \\
\hline Female & 6.25 & 6.88 & 8.52 & 12.26 & 16.36 & 21.09 & 25.17 & 13.35 \\
\hline Wage gap & $3.10 \%$ & $5.10 \%$ & $6.78 \%$ & $6.05 \%$ & $13.30 \%$ & $20.17 \%$ & $21.12 \%$ & $13.20 \%$ \\
\hline \multicolumn{9}{|c|}{ Public sector } \\
\hline Male & 8.55 & 10.91 & 14.04 & 18.34 & 24.38 & 32.04 & 37.32 & 20.36 \\
\hline Female & 8.47 & 10.46 & 12.54 & 15.71 & 19.97 & 24.59 & 28.73 & 16.83 \\
\hline Wage gap & $0.93 \%$ & $4.12 \%$ & $10.68 \%$ & $14.34 \%$ & $18.09 \%$ & $23.25 \%$ & $23.02 \%$ & $17.34 \%$ \\
\hline
\end{tabular}

Wage gap is calcalulated as: 1-(female wages/male wage). Source: RDC of the Federal Statistical Office and Statistical Offices of the Länder, Verdienststrukturerhebung, 2010, own calculations. 
Table 2: Variables in the dataset

\begin{tabular}{|c|c|c|c|c|}
\hline \multirow[b]{2}{*}{ Variable } & \multicolumn{2}{|c|}{$\begin{array}{c}\text { Male } \\
(\mathrm{N}=516,854)\end{array}$} & \multicolumn{2}{|c|}{$\begin{array}{c}\text { Female } \\
(\mathrm{N}=424,233)\end{array}$} \\
\hline & Mean & Std. Dev. & Mean & Std. Dev. \\
\hline Hourly wage & 20.42 & 12.98 & 15.76 & 7.71 \\
\hline (potential) experience & 22.47 & 11.10 & 22.43 & 11.47 \\
\hline Years of education & 13.88 & 2.56 & 13.57 & 2.44 \\
\hline Tenure & 10.55 & 10.39 & 11.17 & 10.90 \\
\hline Working hours & 37.56 & 6.67 & 31.48 & 9.79 \\
\hline Full time employment $(0 / 1)$ & 0.89 & 0.31 & 0.53 & 0.50 \\
\hline Public sector employment $(0 / 1)$ & 0.18 & 0.39 & 0.29 & 0.45 \\
\hline Temporary employment $(0 / 1)$ & 0.11 & 0.32 & 0.14 & 0.34 \\
\hline Shift work $(0 / 1)$ & 0.23 & 0.42 & 0.17 & 0.38 \\
\hline East Germany $(0 / 1)$ & 0.18 & 0.39 & 0.22 & 0.41 \\
\hline Craftsman $(0 / 1)$ & 0.41 & 0.49 & 0.11 & 0.32 \\
\hline \multicolumn{5}{|l|}{ Collective barginaing } \\
\hline No collective bargaining $(0 / 1)$ & 0.60 & 0.49 & 0.52 & 0.50 \\
\hline Industry-level bargaining $(0 / 1)$ & 0.32 & 0.47 & 0.39 & 0.49 \\
\hline Firm-level bargaining $(0 / 1)$ & 0.07 & 0.26 & 0.09 & 0.28 \\
\hline \multicolumn{5}{|l|}{ Firm size } \\
\hline $10-49$ employees $(0 / 1)$ & 0.20 & 0.40 & 0.20 & 0.40 \\
\hline $50-249$ employees $(0 / 1)$ & 0.32 & 0.47 & 0.29 & 0.46 \\
\hline $250+$ employees $(0 / 1)$ & 0.48 & 0.50 & 0.51 & 0.50 \\
\hline \multicolumn{5}{|l|}{ Performance group } \\
\hline Managerial duties $(0 / 1)$ & 0.15 & 0.35 & 0.07 & 0.26 \\
\hline Specialist $(0 / 1)$ & 0.24 & 0.43 & 0.20 & 0.40 \\
\hline Experienced employee $(0 / 1)$ & 0.38 & 0.48 & 0.43 & 0.49 \\
\hline No decision-making responsibilities $(0 / 1)$ & 0.16 & 0.37 & 0.16 & 0.36 \\
\hline Simple tasks $(0 / 1)$ & 0.08 & 0.27 & 0.14 & 0.35 \\
\hline
\end{tabular}

Source: RDC of the Federal Statistical Office and Statistical Offices of the Länder, Verdienststrukturerhebung, 2010, own calculations. 
Table 3: Results of quantile \& least square regressions

\begin{tabular}{|c|c|c|c|c|c|c|c|c|}
\hline & $\begin{array}{c}5^{t h} \\
\text { Percentile }\end{array}$ & $\begin{array}{c}10^{t h} \\
\text { Percentile }\end{array}$ & $\begin{array}{c}25^{t h} \\
\text { Percentile }\end{array}$ & $\begin{array}{c}50^{t h} \\
\text { Percentile }\end{array}$ & $\begin{array}{c}75^{\text {th }} \\
\text { Percentile }\end{array}$ & $\begin{array}{c}90^{t h} \\
\text { Percentile }\end{array}$ & $\begin{array}{c}95^{\text {th }} \\
\text { Percentile }\end{array}$ & OLS \\
\hline \multicolumn{9}{|c|}{ (A) No control variables } \\
\hline Female & $\begin{array}{c}-0.073^{* * *} \\
(0.004)\end{array}$ & $\begin{array}{c}-0.126^{* * *} \\
(0.003)\end{array}$ & $\begin{array}{c}-0.152^{* * *} \\
(0.002)\end{array}$ & $\begin{array}{c}-0.183^{* * *} \\
(0.003)\end{array}$ & $\begin{array}{c}-0.248^{* * *} \\
(0.002)\end{array}$ & $\begin{array}{c}-0.322^{* * *} \\
(0.003)\end{array}$ & $\begin{array}{c}-0.338^{* * *} \\
(0.003)\end{array}$ & $\begin{array}{c}-0.204^{* * *} \\
(0.002)\end{array}$ \\
\hline \multicolumn{9}{|c|}{ (B) Human capital variables ${ }^{a}$} \\
\hline Female & $\begin{array}{c}-0.071^{* * *} \\
(0.003)\end{array}$ & $\begin{array}{c}-0.131^{* * *} \\
(0.002)\end{array}$ & $\begin{array}{c}-0.151^{* * *} \\
(0.002)\end{array}$ & $\begin{array}{c}-0.181^{* * *} \\
(0.002)\end{array}$ & $\begin{array}{c}-0.251^{* * *} \\
(0.002)\end{array}$ & $\begin{array}{c}-0.324^{* * *} \\
(0.002)\end{array}$ & $\begin{array}{c}-0.345^{* * *} \\
(0.003)\end{array}$ & $\begin{array}{c}-0.205^{* * *} \\
(0.001)\end{array}$ \\
\hline \multicolumn{9}{|c|}{ (C) Occupation variables ${ }^{b}$} \\
\hline Feamel & $\begin{array}{c}-0.065^{* * *} \\
(0.002)\end{array}$ & $\begin{array}{c}-0.066^{* * *} \\
(0.002)\end{array}$ & $\begin{array}{c}-0.070^{* * *} \\
(0.001)\end{array}$ & $\begin{array}{c}-0.082^{* * *} \\
(0.001)\end{array}$ & $\begin{array}{c}-0.098^{* * *} \\
(0.002)\end{array}$ & $\begin{array}{c}-0.117^{* * *} \\
(0.002)\end{array}$ & $\begin{array}{c}-0.131^{* * *} \\
(0.003)\end{array}$ & $\begin{array}{c}-0.099^{* * *} \\
(0.001)\end{array}$ \\
\hline
\end{tabular}

Notes: The dependent variable is the natural logarithm of the hourly wage, all models additionally control for region. Standard errors are reported in parentheses. Significance levels: ${ }^{*} p<0.05,{ }^{* *} p<0.01,{ }^{* * *} p<0.001 ; \mathrm{N}=282,326$.

${ }^{a}$ Human capital model includes: education, experience, experience ${ }^{2}$, experience ${ }^{3}$,experience ${ }^{4}$, tenure.

${ }^{b}$ Occupational model accounts for: 2-digit-isco, full time, public service, employees of the firm, shift work, collective agreements 2-digit-industry classification, craftsman, performance group and temporary employment in addition to human capital variables.

Source: RDC of the Federal Statistical Office and Statistical Offices of the Länder,Verdienststrukturerhebung, 2010, own calculations.

Table 4: Results of quantile \& least square regressions

\begin{tabular}{|c|c|c|c|c|c|c|c|c|}
\hline & $\begin{array}{c}5^{\text {th }} \\
\text { Percentile }\end{array}$ & $\begin{array}{l}10^{t h} \\
\text { Percentile }\end{array}$ & $\begin{array}{c}25^{\text {th }} \\
\text { Percentile }\end{array}$ & $\begin{array}{c}50^{t h} \\
\text { Percentile }\end{array}$ & $\begin{array}{c}75^{\text {th }} \\
\text { Percentile }\end{array}$ & $\begin{array}{c}90^{\text {th }} \\
\text { Percentile }\end{array}$ & $\begin{array}{c}95^{\text {th }} \\
\text { Percentile }\end{array}$ & OLS \\
\hline \multicolumn{9}{|c|}{ (A) Germany ( $\mathrm{N}=282,326)$} \\
\hline Female & $\begin{array}{c}-0.065^{* * *} \\
(0.002)\end{array}$ & $\begin{array}{c}-0.066^{* * *} \\
(0.002)\end{array}$ & $\begin{array}{c}-0.070^{* * *} \\
(0.001)\end{array}$ & $\begin{array}{c}-0.082^{* * *} \\
(0.001)\end{array}$ & $\begin{array}{c}-0.098^{* * *} \\
(0.002)\end{array}$ & $\begin{array}{c}-0.117^{* * *} \\
(0.002)\end{array}$ & $\begin{array}{c}-0.131^{* * *} \\
(0.003)\end{array}$ & $\begin{array}{c}-0.099^{* * *} \\
(0.001)\end{array}$ \\
\hline \multicolumn{9}{|c|}{ (B) West Germany $(\mathrm{N}=226,297)$} \\
\hline Female & $\begin{array}{c}-0.066^{* * *} \\
(0.003)\end{array}$ & $\begin{array}{c}-0.065^{\text {*** }} \\
(0.002)\end{array}$ & $\begin{array}{c}-0.071^{* * *} \\
(0.002)\end{array}$ & $\begin{array}{c}-0.080^{* * *} \\
(0.001)\end{array}$ & $\begin{array}{c}-0.096^{* * *} \\
(0.002)\end{array}$ & $\begin{array}{c}-0.119^{* * *} \\
(0.003)\end{array}$ & $\begin{array}{c}-0.134^{* * *} \\
(0.004)\end{array}$ & $\begin{array}{c}-0.100^{* * *} \\
(0.002)\end{array}$ \\
\hline \multicolumn{9}{|c|}{ (C) East Germany $(\mathrm{N}=56,029)$} \\
\hline Female & $\begin{array}{c}-0.048^{* * *} \\
(0.005)\end{array}$ & $\begin{array}{c}-0.060^{* * *} \\
(0.004)\end{array}$ & $\begin{array}{c}-0.057^{* * *} \\
(0.004)\end{array}$ & $\begin{array}{c}-0.066^{* * *} \\
(0.003)\end{array}$ & $\begin{array}{c}-0.078^{* * *} \\
(0.004)\end{array}$ & $\begin{array}{c}-0.097^{* * *} \\
(0.005)\end{array}$ & $\begin{array}{c}-0.107^{* * *} \\
(0.006)\end{array}$ & $\begin{array}{c}-0.085^{* * *} \\
(0.003)\end{array}$ \\
\hline \multicolumn{9}{|c|}{ (D) Public sector $(\mathrm{N}=64,921)$} \\
\hline Female & $\begin{array}{c}-0.017^{* * *} \\
(0.004)\end{array}$ & $\begin{array}{c}-0.020^{* * *} \\
(0.003)\end{array}$ & $\begin{array}{c}-0.024^{* * *} \\
(0.002)\end{array}$ & $\begin{array}{c}-0.025^{* * *} \\
(0.002)\end{array}$ & $\begin{array}{c}-0.039^{* * *} \\
(0.002)\end{array}$ & $\begin{array}{c}-0.047^{* * *} \\
(0.003)\end{array}$ & $\begin{array}{c}-0.052^{* * *} \\
(0.004)\end{array}$ & $\begin{array}{c}-0.052^{* * *} \\
(0.002)\end{array}$ \\
\hline \multicolumn{9}{|c|}{$\begin{array}{l}\text { Notes: The dependent variable is the natural logarithm of the hourly wage. Standard errors are reported in parantheses. } \\
\text { Significance levels: }{ }^{*} p<0.05,{ }^{* *} p<0.01,{ }^{* *} p<0.001 \text {. Estimations are based on } 30 \% \text { subsamples for Germany, } \\
\text { East Germany and West Germany. All models account for: experience, experience }{ }^{2} \text {,experience }{ }^{3} \text {, experience }{ }^{4} \text {, tenure, } \\
\text { 2-digit-isco, full time, public service, employees of the firm, temporary employment, shift work, } 2 \text {-digit-industry } \\
\text { classification, region, craftsman, performance group. Source: RDC of the Federal Statistical Office and Statistical } \\
\text { Offices of the Länder, Verdienststrukturerhebung, 2010, own calculations. }\end{array}$} \\
\hline
\end{tabular}


Table 5: Results of UQ- \& least square regressions

\begin{tabular}{|c|c|c|c|c|c|c|c|c|}
\hline & $\begin{array}{c}5^{t h} \\
\text { Percentile }\end{array}$ & $\begin{array}{c}10^{t h} \\
\text { Percentile }\end{array}$ & $\begin{array}{c}25^{t h} \\
\text { Percentile }\end{array}$ & $\begin{array}{l}50^{t h} \\
\text { Percentile }\end{array}$ & $\begin{array}{l}\quad 75^{t h} \\
\text { Percentile }\end{array}$ & $\begin{array}{c}90^{\text {th }} \\
\text { Percentile }\end{array}$ & $\begin{array}{c}95^{t h} \\
\text { Percentile }\end{array}$ & OLS \\
\hline \multicolumn{9}{|c|}{ (A) Germany $(\mathrm{N}=941,087)$} \\
\hline Female & $\begin{array}{c}-0.032^{* * *} \\
(0.002)\end{array}$ & $\begin{array}{c}-0.037^{* * *} \\
(0.002)\end{array}$ & $\begin{array}{c}-0.060^{* * *} \\
(0.001)\end{array}$ & $\begin{array}{c}-0.081^{* * *} \\
(0.001)\end{array}$ & $\begin{array}{c}-0.131^{* * *} \\
(0.001)\end{array}$ & $\begin{array}{c}-0.179^{* * *} \\
(0.002)\end{array}$ & $\begin{array}{c}-0.203^{* * *} \\
(0.002)\end{array}$ & $\begin{array}{c}-0.100^{* * *} \\
(0.001)\end{array}$ \\
\hline \multicolumn{9}{|c|}{ (B) West Germany $(\mathrm{N}=753,563)$} \\
\hline Female & $\begin{array}{c}-0.029^{* * *} \\
(0.002)\end{array}$ & $\begin{array}{c}-0.063^{* * *} \\
(0.002)\end{array}$ & $\begin{array}{c}-0.064^{* * *} \\
(0.001)\end{array}$ & $\begin{array}{c}-0.084^{* * *} \\
(0.001)\end{array}$ & $\begin{array}{c}-0.131^{* * *} \\
(0.001)\end{array}$ & $\begin{array}{c}-0.172^{* * *} \\
(0.002)\end{array}$ & $\begin{array}{c}-0.197^{* * *} \\
(0.003)\end{array}$ & $\begin{array}{c}-0.101^{* * *} \\
(0.001)\end{array}$ \\
\hline \multicolumn{9}{|c|}{ (C) East Germany $(\mathrm{N}=187,524)$} \\
\hline Female & $\begin{array}{c}-0.027^{* * *} \\
(0.004)\end{array}$ & $\begin{array}{c}-0.041^{* * *} \\
(0.003)\end{array}$ & $\begin{array}{c}-0.064^{* * *} \\
(0.003)\end{array}$ & $\begin{array}{c}-0.065^{* * *} \\
(0.002)\end{array}$ & $\begin{array}{c}-0.084^{* * *} \\
(0.003)\end{array}$ & $\begin{array}{c}-0.151^{* * *} \\
(0.004)\end{array}$ & $\begin{array}{c}-0.194^{* * *} \\
(0.006)\end{array}$ & $\begin{array}{c}-0.085^{* * *} \\
(0.002)\end{array}$ \\
\hline \multicolumn{9}{|c|}{ (D) Public sector $(\mathrm{N}=217,351)$} \\
\hline Female & $\begin{array}{c}-0.014^{* * *} \\
(0.003)\end{array}$ & $\begin{array}{l}0.014^{* * *} \\
(0.003)\end{array}$ & $\begin{array}{c}-0.009^{* * *} \\
(0.002)\end{array}$ & $\begin{array}{c}-0.030^{* * *} \\
(0.002)\end{array}$ & $\begin{array}{c}-0.057^{* * *} \\
(0.002)\end{array}$ & $\begin{array}{c}-0.113^{* * *} \\
(0.003)\end{array}$ & $\begin{array}{c}-0.152^{* * *} \\
(0.004)\end{array}$ & $\begin{array}{c}-0.054^{* * *} \\
(0.001)\end{array}$ \\
\hline
\end{tabular}

Notes: The dependent variable is the natural logarithm of the hourly wage. Standard errors are reported in parantheses. Significance levels: ${ }^{*} p<0.05,{ }^{* *} p<0.01,{ }^{* * *} p<0.001$. All models account for: experience, experience $^{2}$, experience ${ }^{3}$, experience ${ }^{4}$, tenure, 2-digit-isco, full time, public service, employees of the firm, temporary employment, shift work, 2-digit-industry classification, region, craftsman, performance group. Source: RDC of the Federal Statistical Office and Statistical Offices of the Länder, Verdienststrukturerhebung, 2010, own calculations. 
Table 6: Results for the CFM-decomposition

\begin{tabular}{|c|c|c|c|c|c|c|c|c|}
\hline & $\begin{array}{c}5^{\text {th }} \\
\text { Percentile }\end{array}$ & $\begin{array}{c}10^{t h} \\
\text { Percentile }\end{array}$ & $\begin{array}{c}25^{t h} \\
\text { Percentile }\end{array}$ & $\begin{array}{c}50^{t h} \\
\text { Percentile }\end{array}$ & $\begin{array}{c}75^{\text {th }} \\
\text { Percentile }\end{array}$ & $\begin{array}{c}90^{t h} \\
\text { Percentile }\end{array}$ & $\begin{array}{c}95^{\text {th }} \\
\text { Percentile }\end{array}$ & $\begin{array}{l}\text { Oaxaca- } \\
\text { Blinder }\end{array}$ \\
\hline \multicolumn{9}{|c|}{ Germany $(\mathrm{N}=282,326)$} \\
\hline \multicolumn{9}{|c|}{ (A) Male wage structure as reference } \\
\hline Difference & 0.089 & 0.114 & 0.154 & 0.197 & 0.264 & 0.324 & 0.367 & 0.214 \\
\hline Explained & 0.049 & 0.063 & 0.104 & 0.140 & 0.182 & 0.196 & 0.199 & 0.097 \\
\hline Unexplained & 0.040 & 0.051 & 0.050 & 0.058 & 0.083 & 0.127 & 0.168 & 0.116 \\
\hline \multicolumn{9}{|c|}{ (B) Female wage structure as reference } \\
\hline Difference & -0.089 & -0.114 & -0.154 & -0.197 & -0.264 & -0.324 & -0.367 & -0.214 \\
\hline Explained & -0.021 & -0.027 & -0.048 & -0.088 & -0.143 & -0.171 & -0.171 & -0.139 \\
\hline Unexplained & -0.068 & -0.087 & -0.106 & -0.109 & -0.122 & -0.152 & -0.196 & -0.074 \\
\hline \multicolumn{9}{|c|}{ West Germany $(\mathrm{N}=226,297)$} \\
\hline \multicolumn{9}{|c|}{ (C) Male wage structure as reference } \\
\hline Difference & 0.111 & 0.139 & 0.177 & 0.209 & 0.275 & 0.328 & 0.368 & 0.229 \\
\hline Explained & 0.086 & 0.102 & 0.131 & 0.148 & 0.188 & 0.198 & 0.205 & 0.111 \\
\hline Unexplained & 0.025 & 0.037 & 0.046 & 0.061 & 0.087 & 0.131 & 0.163 & 0.118 \\
\hline \multicolumn{9}{|c|}{ (D) Female wage structure as reference } \\
\hline Difference & -0.111 & -0.139 & -0.177 & -0.209 & -0.275 & -0.328 & -0.368 & -0.229 \\
\hline Explained & -0.038 & -0.047 & -0.068 & -0.100 & -0.154 & -0.178 & -0.179 & -0.155 \\
\hline Unexplained & -0.073 & -0.093 & -0.109 & -0.109 & -0.120 & -0.150 & -0.189 & -0.074 \\
\hline
\end{tabular}

East Germany $(\mathrm{N}=56,029)$

(E) Male wage structure as reference

\begin{tabular}{|c|c|c|c|c|c|c|c|c|}
\hline Difference & 0.055 & 0.052 & 0.057 & 0.071 & 0.133 & 0.212 & 0.230 & 0.105 \\
\hline Explained & -0.008 & -0.005 & 0.005 & 0.032 & 0.077 & 0.103 & 0.087 & 0.011 \\
\hline Unexplained & 0.063 & 0.057 & 0.052 & 0.038 & 0.056 & 0.109 & 0.143 & 0.094 \\
\hline
\end{tabular}

(F) Female wage structure as reference

\begin{tabular}{lrrrrrrrr}
\hline Difference & -0.055 & -0.052 & -0.057 & -0.071 & -0.133 & -0.212 & -0.230 & -0.105 \\
Explained & 0.013 & 0.021 & 0.025 & 0.018 & -0.034 & -0.093 & -0.107 & -0.043 \\
Unexplained & -0.067 & -0.072 & -0.083 & -0.089 & -0.099 & -0.120 & -0.122 & -0.062 \\
\hline \hline
\end{tabular}

Public sector $(\mathrm{N}=64,921)$

(G) Male wage structure as reference

\begin{tabular}{lrrrrrrrr}
\hline Difference & 0.028 & 0.046 & 0.120 & 0.158 & 0.207 & 0.236 & 0.234 & 0.152 \\
Explained & 0.058 & 0.073 & 0.115 & 0.136 & 0.167 & 0.161 & 0.144 & 0.086 \\
Unexplained & -0.029 & -0.027 & 0.005 & 0.022 & 0.039 & 0.075 & 0.090 & 0.066 \\
\hline
\end{tabular}

(H) Female wage structure as reference

\begin{tabular}{lrlllllll}
\hline Difference & -0.028 & -0.046 & -0.120 & -0.158 & -0.207 & -0.236 & -0.234 & -0.152 \\
Explained & 0.025 & -0.003 & -0.074 & -0.105 & -0.136 & -0.146 & -0.109 & -0.116 \\
Unexplained & -0.054 & -0.042 & -0.046 & -0.053 & -0.071 & -0.090 & -0.125 & -0.035 \\
\hline
\end{tabular}

Notes: The dependent variable is the natural logarithm of the hourly wage. Estimations are based on 30\% subsamples for Germany, East Germany and West Germany. All models account for: experience, experience ${ }^{2}$,experience ${ }^{3}$,experience ${ }^{4}$, tenure, 2-digit-isco, full time, public service, employees of the firm, temporary employment, shift work, 2-digit-industry classification, region, craftsman, performance group. Source: RDC of the Federal Statistical Office and Statistical Offices of the Länder, Verdienststrukturerhebung, 2010, own calculations. 
Table 7: Results including bonus payments

\begin{tabular}{|c|c|c|c|c|c|c|c|c|}
\hline & $\begin{array}{c}5^{t h} \\
\text { Percentile }\end{array}$ & $\begin{array}{c}10^{t h} \\
\text { Percentile }\end{array}$ & $\begin{array}{c}25^{t h} \\
\text { Percentile }\end{array}$ & $\begin{array}{c}50^{t h} \\
\text { Percentile }\end{array}$ & $\begin{array}{c}75^{t h} \\
\text { Percentile }\end{array}$ & $\begin{array}{c}90^{t h} \\
\text { Percentile }\end{array}$ & $\begin{array}{c}95^{\text {th }} \\
\text { Percentile }\end{array}$ & OLS \\
\hline \multicolumn{9}{|c|}{ (A) CQR $(\mathrm{N}=281,435)$} \\
\hline Female & $\begin{array}{c}-0.072^{* * *} \\
(0.001)\end{array}$ & $\begin{array}{c}-0.070^{* * *} \\
(0.002)\end{array}$ & $\begin{array}{c}-0.078^{* * *} \\
(0.002)\end{array}$ & $\begin{array}{c}-0.086^{* * *} \\
(0.001)\end{array}$ & $\begin{array}{c}-0.103^{* * *} \\
(0.001)\end{array}$ & $\begin{array}{c}-0.122^{* * *} \\
(0.004)\end{array}$ & $\begin{array}{c}-0.135^{* * *} \\
(0.005)\end{array}$ & $\begin{array}{c}-0.116^{* * *} \\
(0.002)\end{array}$ \\
\hline \multicolumn{9}{|c|}{ (B) UQR (N=938,252) } \\
\hline Female & $\begin{array}{c}-0.040^{* * *} \\
(0.002)\end{array}$ & $\begin{array}{c}-0.052^{* * *} \\
(0.002)\end{array}$ & $\begin{array}{c}-0.066^{* * *} \\
(0.001)\end{array}$ & $\begin{array}{c}-0.086^{* * *} \\
(0.001)\end{array}$ & $\begin{array}{c}-0.139^{* * *} \\
(0.001)\end{array}$ & $\begin{array}{c}-0.198^{* * *} \\
(0.002)\end{array}$ & $\begin{array}{c}-0.215^{* * *} \\
(0.003)\end{array}$ & $\begin{array}{c}-0.107^{* * *} \\
(0.001)\end{array}$ \\
\hline \multicolumn{9}{|c|}{ (C) CFM-decomposition - Male wage structure } \\
\hline Difference & 0.107 & 0.117 & 0.150 & 0.198 & 0.274 & 0.349 & 0.405 & 0.220 \\
\hline Explained & 0.052 & 0.057 & 0.093 & 0.138 & 0.187 & 0.203 & 0.209 & 0.095 \\
\hline Unexplained & 0.055 & 0.060 & 0.057 & 0.061 & 0.087 & 0.146 & 0.196 & 0.013 \\
\hline \multicolumn{9}{|c|}{ (D) CFM-decomposition - Female wage structure } \\
\hline Difference & -0.107 & -0.117 & -0.150 & -0.198 & -0.274 & -0.349 & -0.405 & -0.220 \\
\hline Explained & -0.017 & -0.021 & -0.043 & -0.088 & -0.140 & -0.173 & -0.177 & -0.140 \\
\hline Unexplained & -0.090 & -0.096 & -0.107 & -0.111 & -0.134 & -0.177 & -0.227 & -0.80 \\
\hline
\end{tabular}

Notes: The dependent variable is the natural logarithm of the hourly wage including bonus payments. Standard errors are reported in parantheses. Significance levels: ${ }^{*} p<0.05,{ }^{* *} p<0.01,{ }^{* * *} p<0.001$. All models account for: experience, experience $^{2}$, experience ${ }^{3}$, experience ${ }^{4}$, tenure, 2-digit-isco, full time, public service, employees of the firm, temporary employment, shift work, 2-digit-industry classification, region, craftsman, performance group. Source: RDC of the Federal Statistical Office and Statistical Offices of the Länder, Verdienststrukturerhebung, 2010, own calculations. 


\section{Figures}
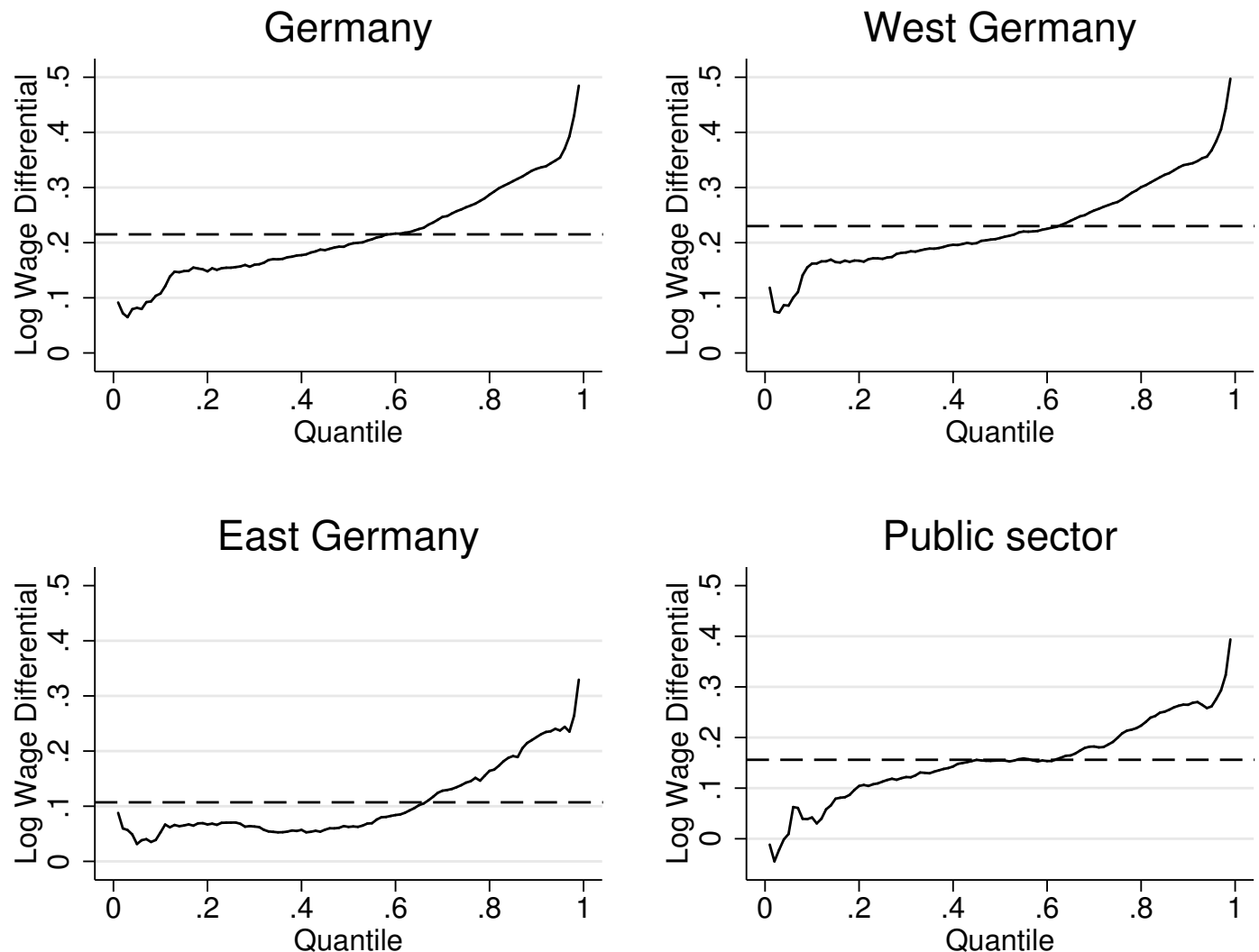

Source: RDC of the Federal Statistical Office and Statistical Offices of the Länder, Verdienststrukturerhebung, 2010, own calculations.

Figure 1: Wage gap per percentile and mean wage gap for the full sample and subsamples of interest. The dashed lines show the mean wage gaps. 

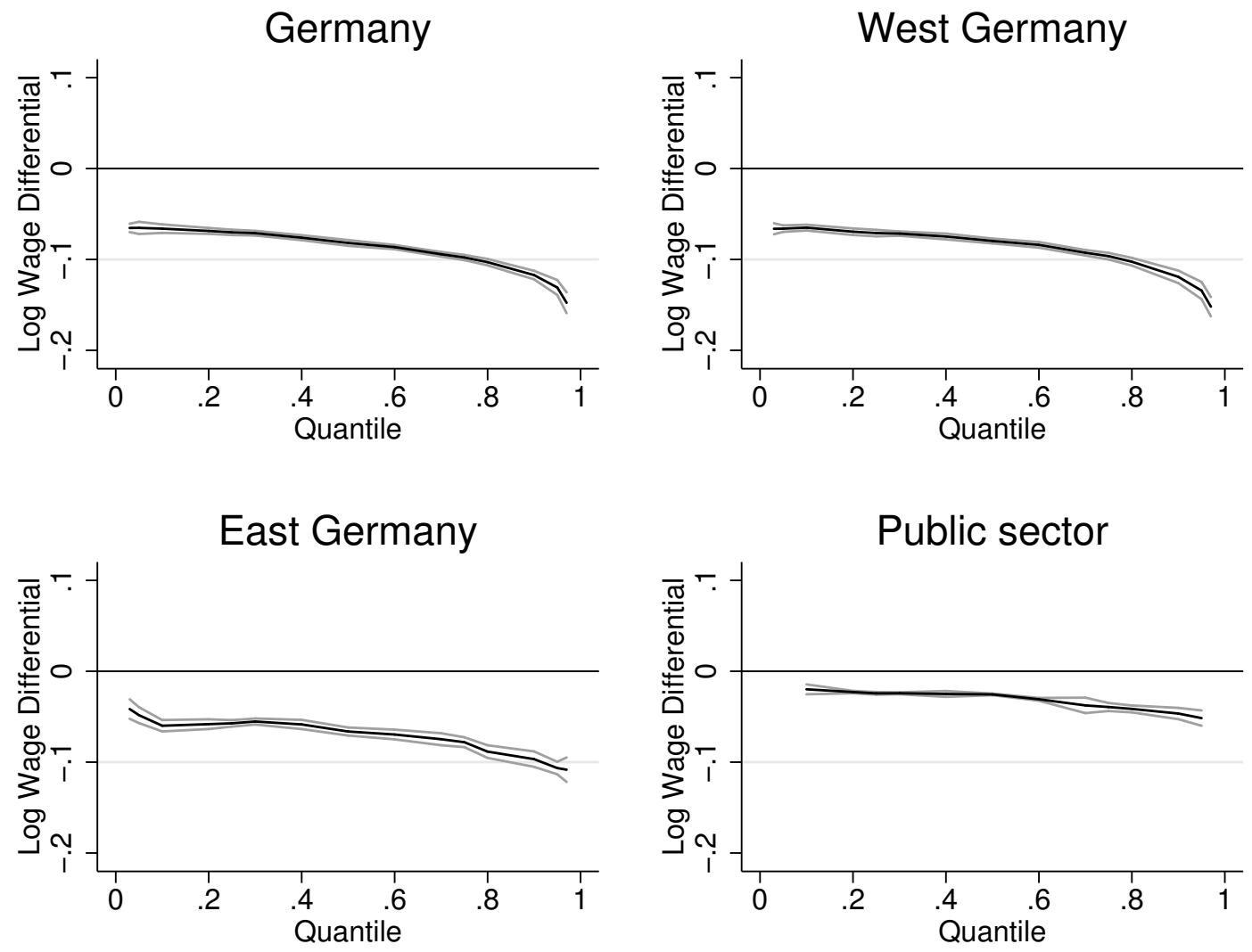

Source: RDC of the Federal Statistical Office and Statistical Offices of the Länder, Verdienststrukturerhebung, 2010, own calculations.

Figure 2: Wage gaps obtained from CQRs with 95\%-CIs (corresponding to Table 4). 
Germany

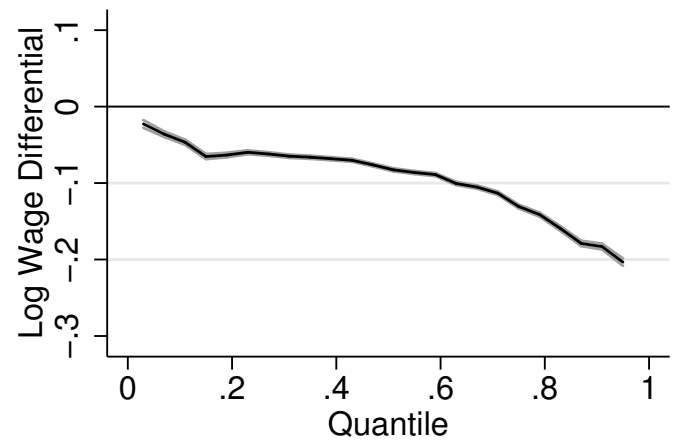

East Germany

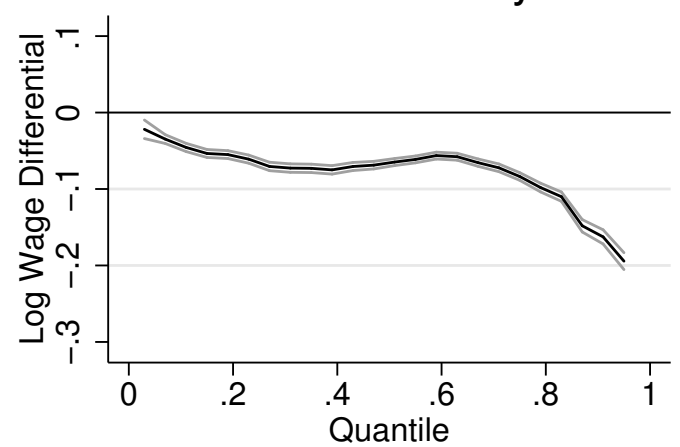

West Germany

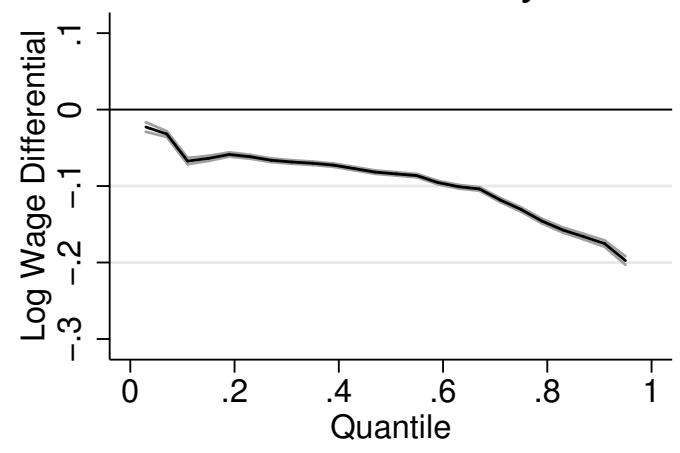

Public sector

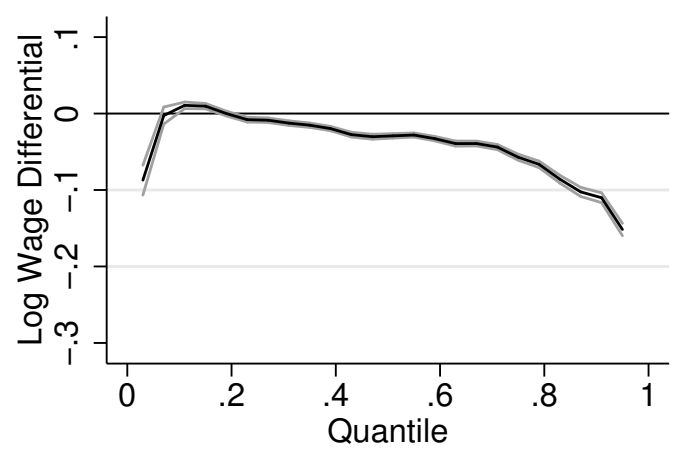

Source: RDC of the Federal Statistical Office and Statistical Offices of the Länder, Verdienststrukturerhebung, 2010, own calculations.

Figure 3: Wage gaps obtained from UQRs with 95\%-CIs (corresponding to Table 5). 

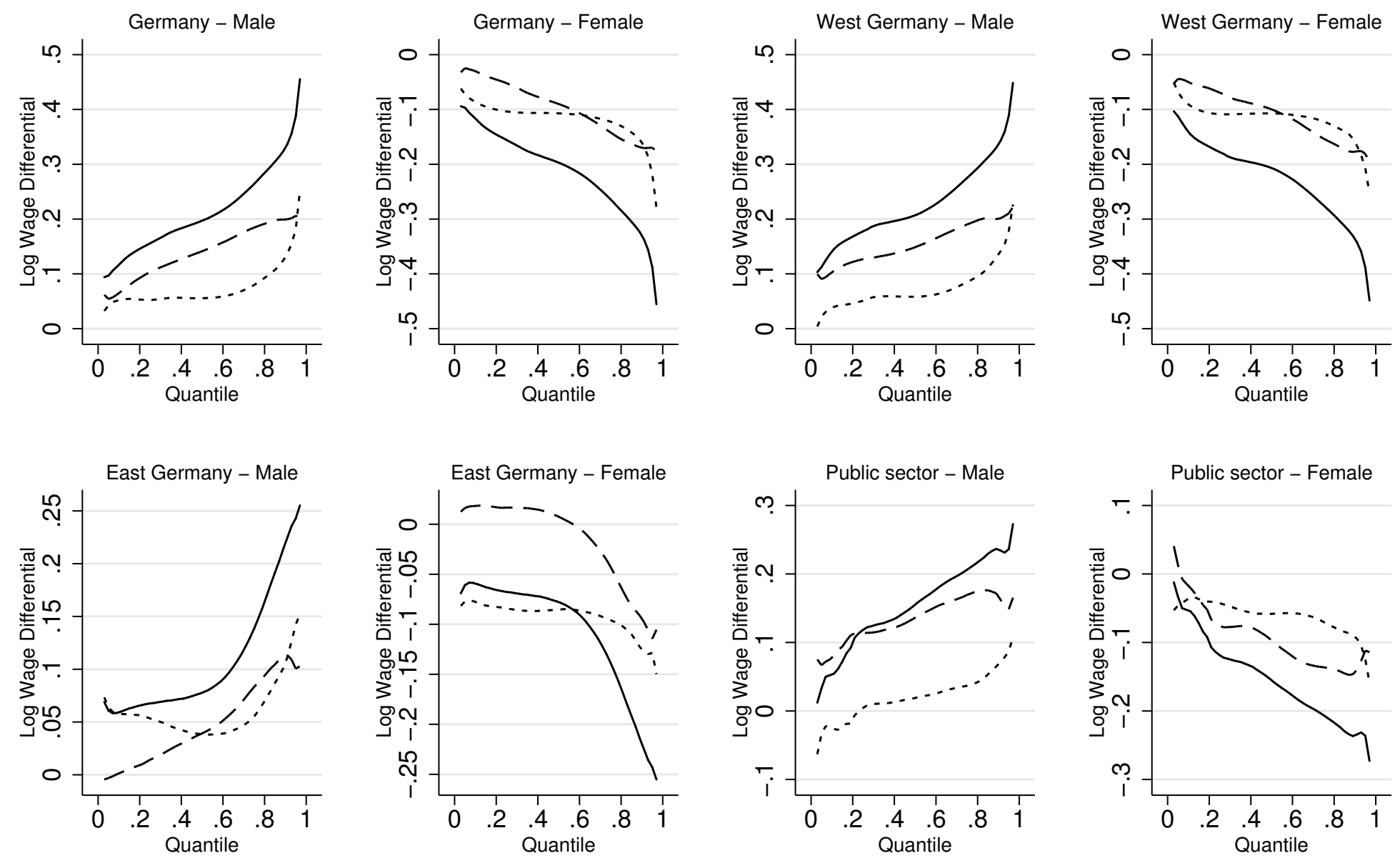

\section{Total difference $\quad$ - - - - Explained (-......... Unexplained}

Source: RDC of the Federal Statistical Office and Statistical Offices of the Länder, Verdienststrukturerhebung, 2010, own calculations.

Figure 4: Wage gaps obtained from CFM decompositions (corresponding to Table 6); Male/Female indicates the reference group and wage structure. 

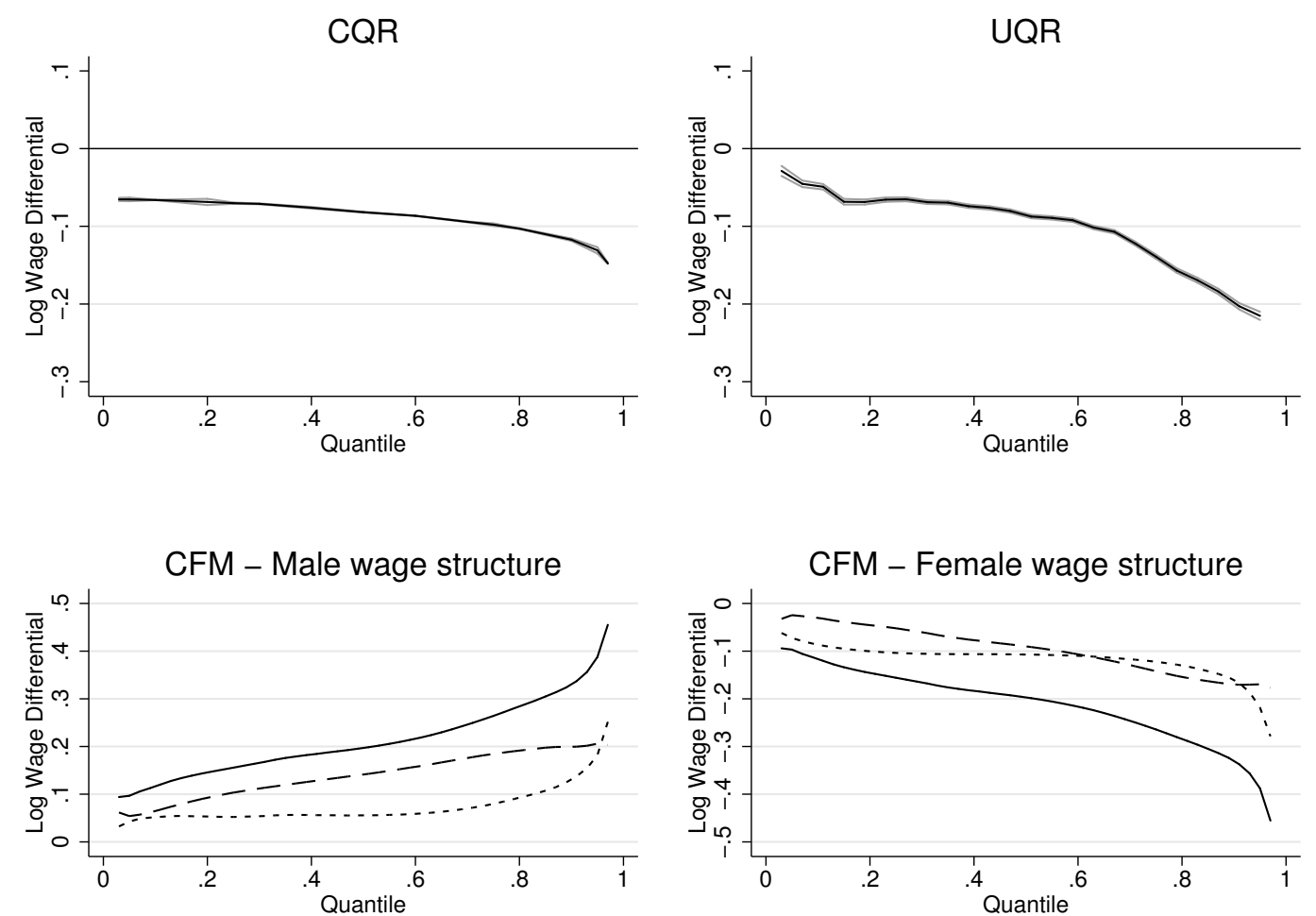

$$
\text { Total difference } \quad--- \text { Explained } \quad \ldots \ldots \text { Unexplained }
$$

Source: RDC of the Federal Statistical Office and Statistical Offices of the Länder, Verdienststrukturerhebung, 2010, own calculations.

Figure 5: Wage gaps including bonus payments for the full sample with 95\%-CIs (for CQR and UQR; corresponding to Table 7). 


\section{Appendix}

\section{A simulation exercise}

For better illustration, I simulate data to show differences between the estimation methods. I generated a sample of 3000 men and 3000 women whose wages are normally distributed with a mean of EUR 2600 and standard deviation of EUR 400. The only covariate in the data is education which can be either high or low. 1000 men and 2000 women are highly educated in this example. High education is randomly distributed within groups and its assignment is not correlated with preeducation wages. To illustrate the methodological differences, highly educated men earn additional wages of EUR 1000 and highly educated women earn additional wages of EUR 500. This results in mean wages of EUR 2930 for men and EUR 2926 for women. The coefficients are presented in EUR.

Table A1, panel A shows wage gaps obtained with OLS, UQR and CQR in the estimations without additional covariates. The estimations hardly differ, because without covariates, the methods simply compare the wage distributions of men and women. Women are more often highly educated in this sample, so the 10th and 50th percentile show positive wage gaps towards women while the 90th percentile has a negative wage effect for women. This is due to the higher premium for high education for men in the simulated data. Because the mean wages for men and women are practically identical, the OLS-estimation delivers a wage gap of EUR 4, which is exactly the mean wage differential between the groups.

Table A1 panel B shows the regression results for the different methods, accounting for education. The CQR results do not indicate a glass ceiling effect, because the wage differences in the conditional distributions for men and women with comparable education hardly vary across the wage distributions. The wage differential between men and women in the wage distribution for loweducated is close to EUR 0, while the wage differential is close to EUR 500 in the highly-educated wage distribution. Thus, the average gender wage differential from both conditional distributions is around EUR 250. In contrast, UQR indicates a glass ceiling effect because the estimation is based on the unconditional wage distribution in which men have higher wages in the upper parts of the 
wage distribution compared to women due to their higher reward for high education.

In contrast to the $\mathrm{CQR}$, the $\mathrm{CFM}$ decompositions indicate a glass ceiling effect as well. This is because this decomposition method constructs counterfactual densities by estimating separate quantile regression for both genders. This way, the different returns to education for both group are counted towards the unexplained wage gaps. The unexplained gap increases across the counterfactual distribution regardless of the wage structure because educated individuals earn higher wages and are therefore more likely to be placed in higher percentiles of the distributions. Therefore, a larger share of the gap is attributable to different returns to education in upper wage groups, while the frequency of high education differs in the lower quantiles, thereby decreasing the unexplained gap in these estimations. The model also shows that, due to different returns to education in this case, the results vary by the reference wage structure. Women are better endowed in education, but have lower returns to education. This leads to large differences in the unexplained wage gaps at the median and the mean between the decompositions. This stresses the importance of using both reference structures in the estimations.

Table A1: CQR, UQR and CFM wage gaps in comparison

\begin{tabular}{|c|c|c|c|c|}
\hline Method & 10th Percentile & 50th Percentile & 90th Percentile & $\mathrm{OLS}^{a}$ \\
\hline \multicolumn{5}{|c|}{ (A) gender only; no additional covariates } \\
\hline CQR & 140 & 83 & -288 & -4 \\
\hline UQR & 127 & 83 & -289 & -4 \\
\hline \multicolumn{5}{|c|}{ (B) with education } \\
\hline CQR & -214 & -247 & -236 & -247 \\
\hline UQR & -27 & -193 & -571 & -247 \\
\hline CFM - Male ref. $b$ & 61 & 384 & 484 & 162 \\
\hline CFM - Female ref. ${ }^{b}$ & -28 & -102 & -416 & -331 \\
\hline
\end{tabular}

